Boise State University

ScholarWorks

$6-2014$

\title{
U-Pb Zircon Geochronology of Roxbury Conglomerate, Boston Basin, Massachusetts: Tectono-stratigraphic Implications for Avalonia in and Beyond SE New England
}

Margaret D. Thompson

Wellesley College

Jahandar Ramezani

Massachusetts Institute of Technology

James L. Crowley

Boise State University 


\title{
U-Pb ZIRCON GEOCHRONOLOGY OF ROXBURY CONGLOMERATE, BOSTON BASIN, MASSACHUSETTS: TECTONO-STRATIGRAPHIC IMPLICATIONS FOR AVALONIA IN AND BEYOND SE NEW ENGLAND
}

\author{
MARGARET D. THOMPSON*, JAHANDAR RAMEZANI**, \\ and JAMES L. CROWLEY***
}

\begin{abstract}
High-precision CA-TIMS ${ }^{206} \mathrm{~Pb} /{ }^{238} \mathrm{U}$ zircon dates from sandstone and Brighton igneous rocks associated with Roxbury Conglomerate in the Boston Basin, eastern Massachusetts provide constraints on the age and tectonic significance of these deposits. Detrital zircon suites from Roxbury-related sandstones representing, in ascending order, the Franklin Park Member (proposed name), the Brookline Member and the Squantum Member establish closely comparable maximum depositional ages of 595.14 $\pm 0.90,598.87 \pm 0.71$ and $596.39 \pm 0.79 \mathrm{Ma}$, respectively. The youngest of these is the best maximum age estimate of the conglomerate. Brighton dacite near the base of the Brookline Member and amygdaloidal andesite near the top yield respective crystallization ages of $584.19 \pm 0.70 \mathrm{Ma}$ and $585.37 \pm 0.72 \mathrm{Ma}$. These virtually identical dates support previous interpretations of these particular units as shallow intrusions and thus represent minimum ages of associated conglomerate. The RoxburyBrighton sequence is traditionally shown as inter-fingering northward with $\leq 570 \mathrm{Ma}$ mudstone of the Cambridge "Argillite," but the age range of the conglomerate makes this impossible. Conglomerate lacking quartzite clasts typical of the Roxbury proper and associated with $593.19 \pm 0.73$ Ma rhyolite on the south side of the basin is re-assigned to the Lynn-Mattapan Volcanic Complex which rests unconformably on Dedham Granite in basement exposed west and north of the basin as well.

Calc-alkaline geochemistry and ages of the 609 to 584 Ma Dedham-Lynn-MattapanBrighton assemblage link it with 630 to $580 \mathrm{Ma}$ arc sequences in other northern Appalachian Avalonian terranes. Roxbury Conglomerate accumulated in faultbounded intra-arc basins near the end of this magmatic cycle.
\end{abstract}

Key words: Roxbury Conglomerate, Brighton Igneous Suite, U-Pb geochronology, Boston Basin, Avalonia

INTRODUCTION AND AVALONIAN SETTING OF THE BOSTON BASIN

Batholithic expanses of Precambrian granite locally overlain by shales containing Cambrian fossils (Billings, 1929; Dowse, 1950) provided the first stratigraphic evidence linking southeastern New England with the Avalon Peninsula of Newfoundland (Rodgers, 1967 and 1972; Rast and others, 1976; Williams, 1978; Skehan and others, 1978). Reliable age constraints needed to establish detailed stratigraphic correlations and tectonic relationships with eastern Newfoundland and other northern Appalachian Avalonian terranes (fig. 1), however, have only emerged in the last twenty years (table 1). Before that, ages could only be inferred for volcanic and other sedimentary rocks overlying SE New England granites (Emerson, 1917; Billings, 1929; LaForge, 1932). In particular, nearly 50 years after Billings' first work in the Boston Basin sector of southeastern New England (fig. 2), Roxbury Conglomerate and Cambridge Argillite (jointly forming the Boston Bay Group starting with LaForge, 1932) still appeared as "Pennsylvanian (?)" (Billings, 1976). This interpretation rested on the presence of possible tree trunk fossils (Burr and Burke, 1900; later discredited by Bailey and Newman, 1978) suggesting similarity with Carboniferous deposits in the more south-

\footnotetext{
edu

* Department of Geosciences, Wellesley College, Wellesley, Massachusetts 02481; mthompso@wellesley.

** Department of Earth, Atmospheric and Planetary Sciences, MIT, Cambridge, Massachusetts 02139 *** Department of Geosciences, Boise State University, Boise, Idaho 83725-1535
} 


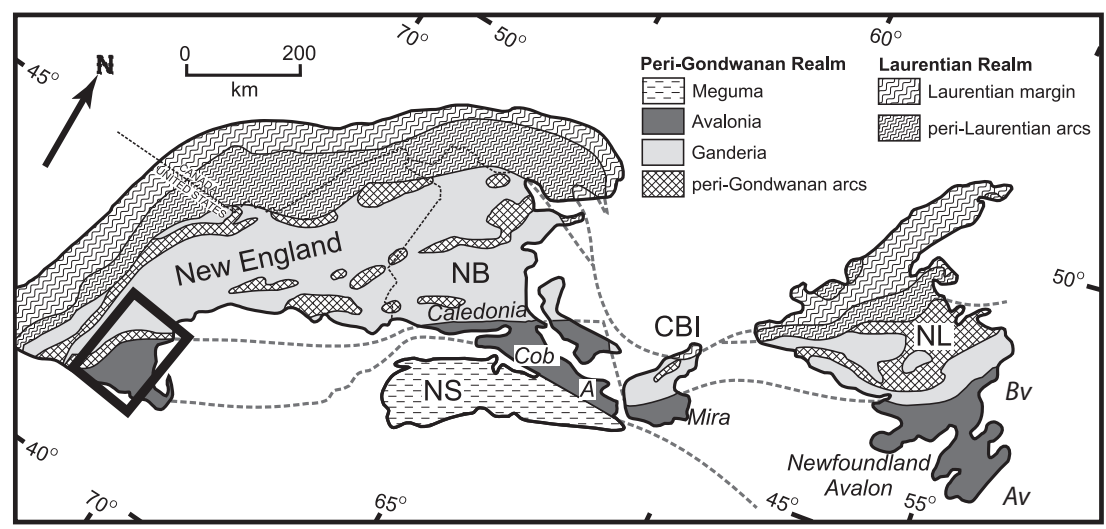

Fig. 1. Lithotectonic components of the northern Appalachian orogen (after Hibbard and others, 2006) showing the distribution of Avalonia and the location of its southeastern New England segment in figure 2 (box). Abbreviations: A-Antigonish Highlands, Av-Avalon Peninsula, Bv—Bonavista Peninsula, CBI-Cape Breton Island, Cob—Cobequid Highlands, NB-New Brunswick, NL—Newfoundland, NSNova Scotia.

erly Narragansett Basin (fig. 2). Lynn-Mattapan volcanic rocks, respectively underlying highlands located to the north and to the south and west of Boston appeared as "Mississippian (?)" in order to be old enough to provide clasts observed in the Roxbury (fig. 2).

Paleontologic evidence for Precambrian age of the Boston Bay Group soon emerged when Ediacaran microfossils were found in Cambridge Argillite during subway tunnel construction north of Harvard Square (Vendian in Lenk and others, 1982). Around the same time, pioneering U-Pb zircon geochronology by USGS geologist Robert Zartman and colleagues yielded Late Precambrian absolute ages for the Mattapan Volcanic Complex (Kaye and Zartman, 1980), combined samples of Dedham and Milford granites (Zartman and Naylor, 1984) and Esmond Granite (Hermes and Zartman, 1985; fig. 2). These dates (though significantly refined in recent years; table 1 and discussion in Thompson and others, 2010) were historically central in assigning plutonic and volcanic rocks in southeastern New England to 630 to 580 Ma subduction-related assemblages in other segments of Avalonia ("younger Neoproterozoic magmatic arcs" of Hibbard and others, 2006; figs. 1 and 2).

$\mathrm{U}-\mathrm{Pb}$ geochronology has so far provided only maximum depositional ages for members of the Boston Bay Group: $<595$ Ma for the top of the Roxbury Conglomerate in Squantum, Massachusetts and $\leq 570$ Ma for Cambridge Argillite in Somerville, MA (Thompson and Bowring, 2000; fig. 2). These deposits are generally interpreted in terms of the tectonic transition between main-phase subduction recorded in the 630 to $580 \mathrm{Ma}$ arc suite and clastic shelf deposition terminating the Avalonian cycle (Hibbard and others, 2006). The chronology of this transition in southeastern New England, however, remains uncertain in the absence of absolute isotopic age constraints. This paper fills that gap by presenting chemical abrasion-thermal ionization mass spectrometry [CA-TIMS] ${ }^{206} \mathrm{~Pb} /{ }^{238} \mathrm{U}$ zircon dates from igneous rocks associated with conglomerate in three locations around the Boston Basin. Complete detrital zircon age spectra obtained via laser ablation-inductively coupled mass spectrometry [LA-ICPMS] are also presented for three Roxbury-related sandstones. These spectra show differing age distributions that suggest conglomerate sedimentation in multiple depocenters controlled by Ediacaran normal faults and supplied by changing source rocks over time.

Revised stratigraphic and structural interpretations are shown in a new geologic map (fig. 3) that differs from previous representations of the Boston Basin (Crosby, 
TABLE 1

U-Pb zircon age constraints on Neoproterozoic bedrock in the SE New England Avalon Zone

\begin{tabular}{|c|c|c|c|c|c|c|}
\hline \multirow[t]{3}{*}{ ROCK FORMATION } & \multicolumn{6}{|c|}{ ISOTOPIC DATE* (MILLIONS OF YEARS) } \\
\hline & \multirow{2}{*}{$\begin{array}{c}\text { Through } \\
1985 \dagger\end{array}$} & \multicolumn{5}{|c|}{ Current Constraint } \\
\hline & & $\begin{array}{c}\text { Lower } \\
\text { intercept date }\end{array}$ & $\begin{array}{c}\text { Upper } \\
\text { intercept date }\end{array}$ & $\begin{array}{c}{ }^{207} \mathrm{~Pb} /{ }^{206} \mathrm{~Pb} \\
\text { date }\end{array}$ & $\begin{array}{c}{ }^{206} \mathrm{~Pb} /{ }^{238} \mathrm{U} \\
\text { date }\end{array}$ & Source \\
\hline Cambridge Argillite & no data & & $\leq 570$ & & & 1 \\
\hline Brighton Igneous Suite & no data & & & & $\begin{array}{l}584.19 \pm 0.70 \\
585.37 \pm 0.72\end{array}$ & $\begin{array}{l}\text { This study } \\
\text { This study }\end{array}$ \\
\hline $\begin{array}{l}\text { Roxbury Conglomerate } \\
\text { Squantum, MA } \\
\text { Newton, MA } \\
\text { Franklin Park, Boston }\end{array}$ & $\begin{array}{l}\text { no data } \\
\text { no data } \\
\text { no data }\end{array}$ & & & & $\begin{array}{l}<596.39 \pm 0.79 \\
<598.87 \pm 0.71 \\
<595.14 \pm 0.90 \\
\end{array}$ & $\begin{array}{l}\text { This study } \\
\text { This study } \\
\text { This study }\end{array}$ \\
\hline Westwood quartz diorite & no data & & $589 \pm 2$ & & & 2 \\
\hline Dartmouth Pluton & no data & & $595 \pm 5$ & & & 3 \\
\hline Lynn Volcanic Complex & no data & & $596 \pm 3$ & & $595.8 \pm 1.2$ & $\begin{array}{l}4 \\
5\end{array}$ \\
\hline $\begin{array}{l}\text { Mattapan Volcanic } \\
\text { Complex }\end{array}$ & $602 \pm 3^{6}$ & & $596 \pm 2$ & $597.4 \pm 1.5$ & $\begin{array}{c}593.19 \pm 0.73 \\
596.0 \pm 1.4 \\
595.7 \pm 1.6\end{array}$ & $\begin{array}{c}\text { This study } \\
4 \\
4 \\
4 \\
2 \\
\end{array}$ \\
\hline Esmond Granite & $621 \pm 8^{7}$ & & & & $599 \pm 2$ & 8 \\
\hline Westwood Granite & no data & & $599 \pm 1$ & & & 2 \\
\hline Cohasset Granite & no data & & $599 \pm 2$ & & & 9 \\
\hline Fall River Granite & $\begin{array}{c}584 \pm 7^{10} \\
631 \pm 10^{10}\end{array}$ & & & & $604.4 \pm 1.2$ & 8 \\
\hline $\begin{array}{l}\text { Gneisses } \\
\text { Hope Valley Alaskite } \\
\text { Northbridge Gneiss } \\
\text { Ponagansett Gneiss }\end{array}$ & $621 \pm 25^{7}$ & & & $\begin{array}{l}606 \pm 5^{\S} \\
607 \pm 5^{\S} \\
612 \pm 5^{\S}\end{array}$ & & $\begin{array}{l}11 \\
11 \\
11\end{array}$ \\
\hline Milford Granite & $630 \pm 15^{10}$ & & & & $606 \pm 1.2$ & 8 \\
\hline $\begin{array}{l}\text { Dedham Granite } \\
\text { North of Boston }\end{array}$ & no data & $\begin{array}{l}606 \pm 3 \\
607 \pm 4 \\
609 \pm 4\end{array}$ & & & & $\begin{array}{l}5 \\
5 \\
5\end{array}$ \\
\hline Dedham Granite & $630 \pm 15^{10}$ & & & & $\begin{array}{l}608.9 \pm 1.2 \\
609.1 \pm 1.1 \\
609.5 \pm 1.1 \\
\end{array}$ & $\begin{array}{l}8 \\
8 \\
8 \\
\end{array}$ \\
\hline Westboro Formation & $<1500^{12}$ & & & & $<912.23 \pm 0.70$ & 13 \\
\hline
\end{tabular}

* Date is used throughout the paper to denote what has been measured. Dates are interpreted in terms of crystallization or maximum depositional age.

${ }^{+}{ }^{207} \mathrm{~Pb} /{ }^{206} \mathrm{~Pb}$ dates for Fall River Granite; other entries in this column are upper intercept U-Pb dates.

$\S$ Obtained via Sensitive High-resolution Ion Microprobe [SHRIMP]; other entries throughout the table were obtained using Thermal Ionization Mass Spectroscopy [TIMS].

Sources of dates are: 1-Thompson and Bowring, 2000; 2-Thompson and others, 1996; 3-Hermes and Zartman, 1992; 4-Thompson and others, 2007; 5-Hepburn and others, 1993; 6-Kaye and Zartman, 1980; 7-Hermes and Zartman, 1985; 8-Thompson and others, 2010; 9-Dillon and others, 1993, 10-Zartman and Naylor, 1984; 11-Walsh and others, 2009; 12-Olszewski, 1980; 13-Thompson and others, 2012.

1880; Emerson, 1917; Billings, 1929; LaForge, 1932; Billings, 1976; Kaye, 1980; Zen, 1983; Thompson, 1993) in that the ages of all map units are constrained by U-Pb zircon geochronology. The Brighton age constraints on the Roxbury Conglomerate, together with geochemistry of the Brighton suite, imply that this portion of the Boston Bay 


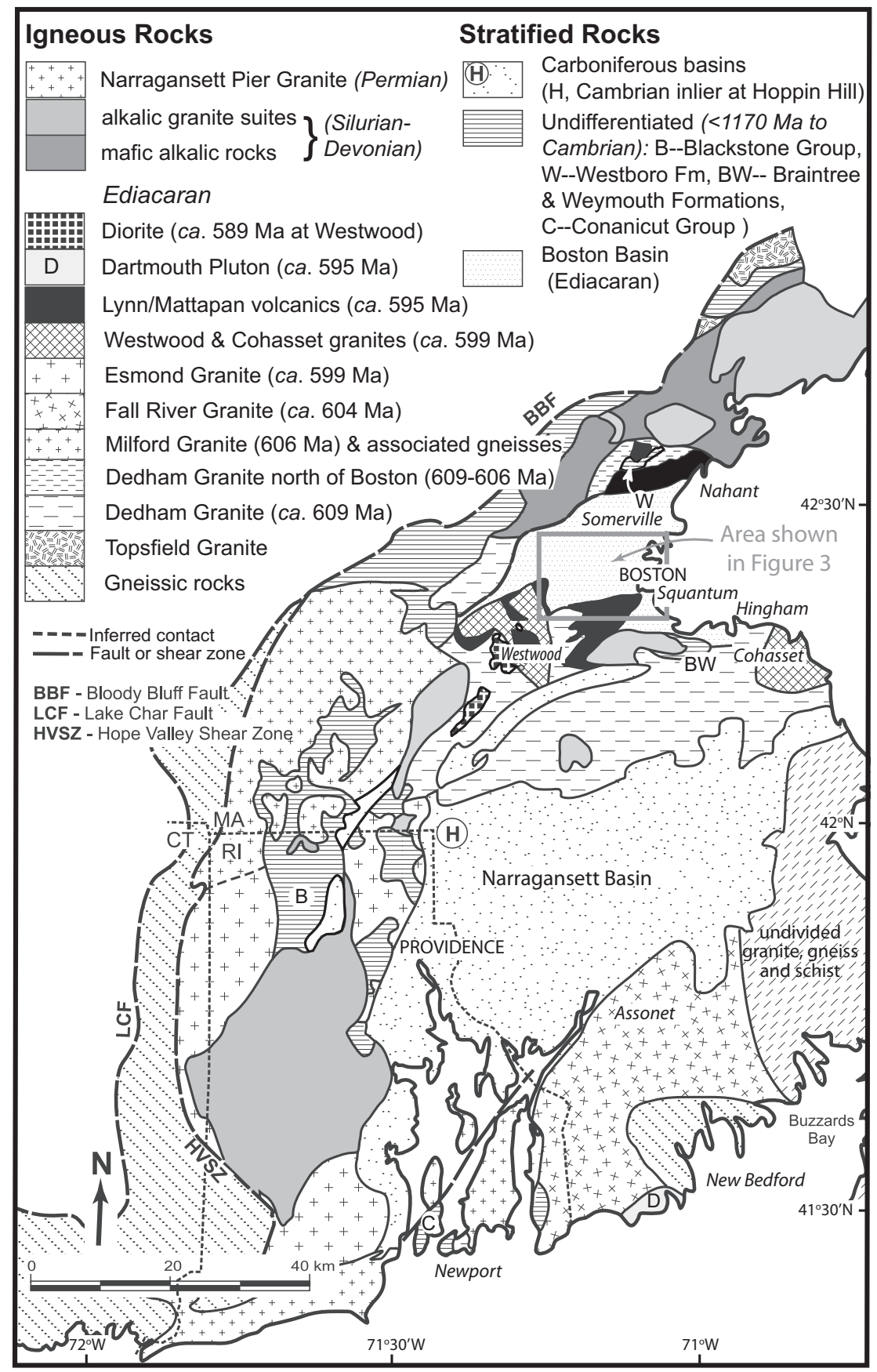

Fig. 2. Simplified geologic map of the Southeastern New England Avalon Zone modified from Thompson and others (2010) showing location of study area in figure 3 (box). Sources, types and uncertainties of dates in the legend are listed in table 1. 
Group developed during waning stages of the Avalonian magmatic arc and that the transition interval leading to platform conditions is restricted to the Cambridge Argillite.

\section{$\mathrm{U}-\mathrm{Pb}$ GEOCHRONOLOGY}

U-Pb zircon geochronology was conducted in this study on six samples collected in various districts and suburbs of Boston, Massachusetts (sample locations in fig. 3). Samples MT03-09A and BOS22A representing the Brighton "Melaphyre" (altered basalt and andesite of Crosby, 1880; Burr, 1901; Emerson, 1917; LaForge, 1932 and Billings, 1976) in the central part of the Boston Basin, and sample MT08-01 from Mattapan rhyolite associated with non-Roxbury conglomerate on the south side of the map area were analyzed via CA-TIMS at the MIT Isotope Lab (methods in Appendix 1). Major and trace element compositions for these samples (along with other unpublished analyses of Mattapan-Brighton suite) appear in table 2. Detrital zircon suites from sandstone samples MT99-4, MT04-20 and MT10-12 representing different geographic locations and stratigraphic levels in the Roxbury Conglomerate were analyzed using a two-phase approach at the Boise State University Isotope Geology Laboratory (methods in Appendix 2). First, laser ablation-inductively coupled plasma spectrometry (LA-ICPMS) revealed the full range of detrital zircon ages including the youngest zircons in each suite. Samples MT10-12 and MT04-20 (fig. 3) provide the first such data from the central portion of the Boston Basin. Sample MT99-4 from the Squantum "tillite" member at the top of the Roxbury Conglomerate (fig. 3) comprises zircon separates remaining after a previous study (twelve TIMS analyses by Thompson and Bowring, 2000 on single, air-abraded zircons). New analyses were undertaken for this sample to establish a complete detrital zircon age profile. In all three cases, 6-10 zircons contributing to the youngest peak in the respective probability density distributions of laser ablation analyses (plotted using AgeDisplay spreadsheet of Sircombe, 2004) were extracted from the epoxy mounts after LA-ICPMS analysis, pretreated using chemical abrasion methods described in Appendix 2, then re-analyzed via CA-TIMS to obtain precise maximum depositional ages. Isotopic data and UTM coordinates for the six samples are shown in tables 3, 4 (http:/ / earth.geology.yale.edu/ ajs/SupplementaryData/2014/14ThompsonTable4.doc), and 5.

The CA-TIMS zircon analyses for igneous samples in this study produced coherent clusters of data for which scatter can be explained by analytical uncertainties alone. Since most high-precision data from CA-TIMS-analyzed zircon exhibit a slight but systematic age discordance (manifested by older ${ }^{207} \mathrm{~Pb} /{ }^{206} \mathrm{~Pb}$ dates relative to the corresponding $\mathrm{Pb} / \mathrm{U}$ dates) likely due to inaccuracy in one or both of the $\mathrm{U}$ decay constants (Mattinson, 2005; Schoene and others, 2006), we consider the weighted mean ${ }^{206} \mathrm{~Pb} /{ }^{238} \mathrm{U}$ date to be the most precise and accurate estimate both for crystallization ages of igneous samples in this study and for detrital zircons in sandstone samples.

A word is also necessary with regard to reporting errors on high precision CA-TIMS dates. We follow Schoene and others (2006) in reporting U-Pb date errors in the form $\pm \mathrm{X} / \mathrm{Y} / \mathrm{Z}$ (table 6 ), where $\mathrm{X}$ is the internal (analytical) uncertainty in the absence of all external errors, $\mathrm{Y}$ incorporates tracer calibration error, and $\mathrm{Z}$ includes the latter as well as the decay constant errors of Jaffey and others (1971). In CA-TIMS isotopic data tables 3 and 5 , errors are shown as $\pm \mathrm{X}$. However, external uncertainties must be taken into account if the results are to be compared with dates obtained in other laboratories, or dates derived from other chronometers like ${ }^{40} \mathrm{Ar} /{ }^{39} \mathrm{Ar}$. Therefore, the more inclusive $\pm \mathrm{Z}$ is stated in sections below and associated figures 4,5 . Errors accompanying these dates are expressed in two significant figures without rounding the decimals, and the dates themselves are carried to two decimal places to correspond with the error. In cases where $\pm \mathrm{Z}>1$ (for example, 609.5 $\pm 1.1 \mathrm{Ma}$ for 
1014 M. D. Thompson E others-U-Pb zircon geochronology of Roxbury Conglomerate,

TABLE 2

Major and trace element compositions of Lynn-Mattapan and Brighton samples

\begin{tabular}{|c|c|c|c|c|c|c|c|c|c|c|c|c|c|}
\hline & $1 *$ & $2 \dagger$ & 3 & 4* & 5 & $6^{*}$ & $7 *$ & $8^{*}$ & 9* & 10 & $11^{*}$ & 12 & $13 *$ \\
\hline \multicolumn{14}{|c|}{ Lynn-Mattapan Volcanic Complex } \\
\hline Field \# & MT179 & MT08 & BOS20 & $\mathrm{C} 109$ & DT27 & MT92 & MT92 & MT92 & MT92 & WE3 & MT92 & WE3 & MT92 \\
\hline & & -01 & -2 & & -184 & -1 & -4 & -3 & -7 & -4 & -6 & -3 & -5 \\
\hline \multicolumn{14}{|c|}{ Major elements (wt \%) } \\
\hline $\mathrm{SiO}_{2}$ & 74.15 & 72.59 & 69.75 & 69.59 & 66.87 & 60.7 & 60.53 & 58.33 & 56.21 & 53.24 & 51.69 & 51.66 & 51.47 \\
\hline $\mathrm{TiO}_{2}$ & 0.17 & 0.33 & 0.57 & 0.96 & 0.57 & 1.04 & 0.92 & 2.62 & 0.98 & 1.30 & 1.19 & 1.34 & 1.33 \\
\hline $\mathrm{Al}_{2} \mathrm{O}_{3}$ & 14.79 & 17.21 & 15.51 & 14.41 & 16.42 & 17.2 & 18.23 & 17.44 & 18.57 & 18.34 & 18.16 & 19.03 & 19.21 \\
\hline $\mathrm{Fe}_{2} \mathrm{O}_{3} \S$ & 1.70 & 1.89 & 3.05 & 4.08 & 4.21 & 7.81 & 7.35 & 8.44 & 8.75 & 8.77 & 10.35 & 9.07 & 11.08 \\
\hline $\mathrm{MnO}$ & 0.04 & 0.04 & 0.11 & 0.13 & 0.07 & 0.12 & 0.06 & 0.11 & 0.11 & 0.15 & 0.16 & 0.17 & 0.2 \\
\hline $\mathrm{MgO}$ & 0.15 & 0.50 & 0.69 & 1.85 & 1.70 & 2.28 & 2.7 & 4.48 & 4.76 & 4.76 & 6.05 & 5.16 & 8.78 \\
\hline $\mathrm{CaO}$ & 0.33 & 0.72 & 1.40 & 3.25 & 3.53 & 4.15 & 2.25 & 2.62 & 3.06 & 7.88 & 4.47 & 7.31 & 1.74 \\
\hline $\mathrm{Na}_{2} \mathrm{O}$ & 3.99 & 2.75 & 4.42 & 1.15 & 5.47 & 4.21 & 4.83 & 5.08 & 5.87 & 2.33 & 5.6 & 3.52 & 5.16 \\
\hline $\mathrm{K}_{2} \mathrm{O}$ & 4.27 & 3.97 & 4.14 & 4.00 & 1.26 & 1.46 & 2.48 & 2.3 & 1.63 & 2.80 & 1.46 & 2.43 & 1.25 \\
\hline $\mathrm{P}_{2} \mathrm{O}_{5}$ & 0.04 & 0.06 & 0.15 & 0.25 & 0.23 & 0.37 & 0.42 & 0.59 & 0.35 & 0.56 & 0.4 & 0.59 & 0.39 \\
\hline Total & 99.63 & 100.06 & 99.79 & 99.67 & 100.33 & 99.34 & 99.77 & 102.01 & 100.29 & 100.13 & 99.53 & 100.28 & 100.61 \\
\hline \multicolumn{14}{|c|}{ Trace elements (ppm) } \\
\hline $\mathrm{Nb}$ & 26.0 & 19.0 & 14.4 & 17.0 & 3.8 & 10 & 7 & 9 & 4 & 9.2 & 5 & 9.1 & 4 \\
\hline $\mathrm{Zr}$ & 280.9 & 358 & 298 & 244.0 & 112 & 213 & 131 & 197 & 107 & 204 & 119 & 212 & 107 \\
\hline Y & 50.7 & 27.4 & 26.1 & 37.0 & 8.5 & 23 & 14 & 19 & 17 & 17.2 & 18 & 17.7 & 17 \\
\hline $\mathrm{Sr}$ & 59 & 293 & 340 & 163 & 741 & 552 & 412 & 359 & 873 & 960 & 556 & 1603 & 873 \\
\hline $\mathrm{U}$ & & 2 & 2 & & 0 & & & & & 0 & & 0 & \\
\hline $\mathrm{Rb}$ & 164.8 & 118.4 & 118.3 & & 34.5 & 24 & 38 & 33 & 33 & 68.9 & 41 & 70.7 & 33 \\
\hline Th & & 11 & 10 & & 1 & & & & & 1 & & 1 & \\
\hline $\mathrm{Pb}$ & & 26 & 15 & & 14 & & & & & 9 & & 9 & \\
\hline $\mathrm{Ga}$ & & 22 & 16 & & 17 & & & & & 19 & & 21 & \\
\hline $\mathrm{Zn}$ & 94.7 & 74 & 67 & 44.0 & 70 & 110 & 91 & 86 & 115 & 121 & 111 & 129 & 115 \\
\hline $\mathrm{Ni}$ & 8.8 & 1 & 2 & & 14 & 31 & 25 & 66 & 133 & 53 & 126 & 55 & 133 \\
\hline $\mathrm{Cr}$ & & 0 & 5 & & 16 & & & & & 82 & & 83 & \\
\hline $\mathrm{V}$ & & 6 & 29 & & 66 & & & & & 177 & & 180 & \\
\hline $\mathrm{Ce}$ & 89.7 & 70 & 73 & 56.0 & 35 & 55 & 47 & 86 & 47 & 60 & 44 & 66 & 47 \\
\hline $\mathrm{Ba}$ & 670.1 & 1096 & 1277 & 584.0 & 618 & 991 & 1434 & 818 & 846 & 1694 & 564 & 1037 & 846 \\
\hline $\mathrm{La}$ & 36.0 & 40 & 31 & 22.0 & 16 & 25 & 47 & 42 & 19 & 27 & 21 & 28 & 19 \\
\hline
\end{tabular}

Dedham Granite at the bottom of table 1), errors reported to two significant figures entail only a single decimal place, so the date itself is likewise carried to one place.

\section{Sample MT08-01}

Flow banded rhyolite (72.59 weight $\% \mathrm{SiO}_{2}$; analysis 2 in table 2) from the Mattapan Volcanic Complex was collected on the south margin of the Boston Basin in Milton, Massachusetts (fig. 3). The rock is studded with single and clustered feldspar euhedra commonly replaced by a mosaic of albite and quartz. A few thoroughly altered biotite grains now replaced by intergrowths of quartz + epidote + muscovite + rutile + apatite are also present. The matrix consists of felty, very fine-grained muscovite and granular patches of epidote and quartz. Accessory minerals include apatite, hematite, ilmenite, rutile and zircon. Four single zircons analyzed from this sample (z1, z3, z4 and z5 in table 3) produced statistically coherent results with a weighted mean ${ }^{206} \mathrm{~Pb} /{ }^{238} \mathrm{U}$ date of $593.19 \pm 0.73 \mathrm{Ma}$ (MSWD [mean square of weighted deviates $]=1.5$ ) interpreted as the crystallization age. A concordia plot of these analyses is shown in figure 4A. A fifth analysis (not plotted in fig. 4A) yielded an older date of $607.88 \pm 0.55 \mathrm{Ma}$ (z2 in table 3 ) probably due to its xenocrystic origin. The above crystallization age compares closely to the dates previously reported for the Mattapan volcanic rocks west and south of the Boston Basin (Thompson and others, 
TABLE 2

(continued)

\begin{tabular}{|c|c|c|c|c|c|c|c|c|c|c|c|c|c|}
\hline & 14 & $15^{*}$ & 16 & 17 & $18 \dagger$ & 19 & $20 \dagger$ & 21 & 22 & 23 & 24 & 25 & 26 \\
\hline & \multicolumn{4}{|c|}{$\begin{array}{l}\text { Lynn-Mattapan Volcanic } \\
\text { Complex }\end{array}$} & \multicolumn{9}{|c|}{ Brighton Igneous Suite } \\
\hline Field \# & $\begin{array}{c}\text { DT34 } \\
-290 \\
\end{array}$ & $\begin{array}{c}\text { MT92 } \\
-2 \\
\end{array}$ & $\begin{array}{c}\text { WE7 } \\
-3 \\
\end{array}$ & $\begin{array}{c}\text { WE7 } \\
-4 \\
\end{array}$ & $\begin{array}{c}\text { MT03 } \\
-09 \\
\end{array}$ & $\begin{array}{c}\text { MT03 } \\
-08 \\
\end{array}$ & $\begin{array}{c}\text { BOS } \\
22 \\
\end{array}$ & $\begin{array}{l}\text { BOS } \\
21 \mathrm{~A} \\
\end{array}$ & $\begin{array}{c}\text { MT03 } \\
-06 \\
\end{array}$ & $\begin{array}{c}\text { MT98 } \\
-29 \\
\end{array}$ & $\begin{array}{c}\text { MT01 } \\
-27 A \\
\end{array}$ & $\begin{array}{l}\mathrm{MT} \\
\text {-R1 } \\
\end{array}$ & $\begin{array}{l}\text { MT01 } \\
-27 \mathrm{~B} \\
\end{array}$ \\
\hline \multicolumn{14}{|c|}{ Major elements (wt \%) } \\
\hline $\mathrm{SiO}_{2}$ & 50.44 & 49.27 & 46.20 & 42.40 & 67.51 & 61.62 & 61.16 & 54.49 & 51.93 & 51.86 & 50.63 & 50.50 & 49.84 \\
\hline $\mathrm{TiO}_{2}$ & 1.66 & 1.88 & 1.40 & 1.37 & 0.96 & 0.97 & 1.00 & 1.18 & 1.55 & 1.27 & 1.26 & 1.25 & 1.27 \\
\hline $\mathrm{Al}_{2} \mathrm{O}_{3}$ & 18.44 & 19.31 & 19.03 & 20.41 & 14.95 & 16.82 & 16.37 & 17.86 & 18.49 & 19.04 & 17.76 & 18.00 & 18.74 \\
\hline $\mathrm{Fe}_{2} \mathrm{O}_{3} \S$ & 11.08 & 11.62 & 13.16 & 13.40 & 5.18 & 5.94 & 7.08 & 8.41 & 8.97 & 9.45 & 11.95 & 9.63 & 11.87 \\
\hline $\mathrm{MnO}$ & 0.16 & 0.14 & 0.19 & 0.26 & 0.08 & 0.11 & 0.14 & 0.14 & 0.16 & 0.2 & 0.31 & 0.17 & 0.30 \\
\hline $\mathrm{MgO}$ & 2.91 & 5.77 & 8.04 & 12.06 & 1.77 & 1.79 & 5.66 & 4.41 & 5.21 & 10.33 & 11.73 & 8.87 & 10.45 \\
\hline $\mathrm{CaO}$ & 7.84 & 2.85 & 7.12 & 6.67 & 1.84 & 5.01 & 2.51 & 6.49 & 5.58 & 1.38 & 1.51 & 6.54 & 1.71 \\
\hline $\mathrm{Na}_{2} \mathrm{O}$ & 5.77 & 3.64 & 3.30 & 2.63 & 6.94 & 5.47 & 5.36 & 3.92 & 4.59 & 5.15 & 3.54 & 4.56 & 3.30 \\
\hline $\mathrm{K}_{2} \mathrm{O}$ & 0.61 & 4.1 & 0.96 & 0.42 & 0.36 & 1.67 & 0.43 & 2.61 & 2.32 & 0.91 & 0.99 & 0.47 & 2.28 \\
\hline $\mathrm{P}_{2} \mathrm{O}_{5}$ & 0.75 & 0.68 & 0.29 & 0.29 & 0.45 & 0.46 & 0.42 & 0.50 & 0.72 & 0.22 & 0.21 & 0.33 & 0.21 \\
\hline Total & 99.66 & 99.26 & 99.69 & 99.91 & 100.04 & 99.86 & 100.13 & 100.01 & 99.52 & 99.81 & 99.89 & 100.32 & 99.97 \\
\hline & \multicolumn{13}{|c|}{ Trace elements (ppm) } \\
\hline $\mathrm{Nb}$ & 13.0 & 23 & 4.2 & 4.0 & 11.7 & 11.8 & 8.6 & 8.1 & 6.4 & 3.1 & 3.0 & 4.0 & 3.2 \\
\hline $\mathrm{Zr}$ & 298 & 228 & 101 & 99 & 222 & 224 & 193 & 199 & 224 & 96 & 96 & 133 & 97 \\
\hline $\mathrm{Y}$ & 28.1 & 29 & 21.6 & 20.8 & 19.3 & 16.7 & 15.7 & 17.6 & 17.5 & 21.3 & 21.1 & 17.0 & 19.4 \\
\hline $\mathrm{Sr}$ & 1467 & 305 & 362 & 278 & 452 & 1010 & 298 & 1619 & 1380 & 320 & 197 & 592 & 192 \\
\hline $\mathrm{U}$ & 0 & & 0 & 0 & 0 & 0 & 0 & 0 & 0 & 0 & 0 & 0 & 0 \\
\hline $\mathrm{Rb}$ & 9.4 & 59 & 23.8 & 8.9 & 5.2 & 8.3 & 6.7 & 25.5 & 22.7 & 22.2 & 28.1 & 3.9 & 68.9 \\
\hline Th & 1 & & 0 & 1 & 2 & 2 & 2 & 1 & 2 & 0 & 0 & 0 & 0 \\
\hline $\mathrm{Pb}$ & 15 & & 8 & 3 & 14 & 30 & 16 & 16 & 25 & 6 & 16 & 10 & 11 \\
\hline $\mathrm{Ga}$ & 27 & & 19 & 18 & 11 & 21 & 14 & 20 & 20 & 18 & 18 & 18 & 19 \\
\hline $\mathrm{Zn}$ & 92 & 108 & 135 & 197 & 81 & 73 & 126 & 101 & 140 & 128 & 127 & 122 & 114 \\
\hline $\mathrm{Ni}$ & 66 & 62 & 175 & 194 & 23 & 21 & 58 & 75 & 49 & 137 & 131 & 163 & 134 \\
\hline $\mathrm{Cr}$ & 113 & & 221 & 190 & 30 & 37 & 57 & 108 & 61 & 211 & 200 & 318 & 201 \\
\hline $\mathrm{V}$ & 204 & & 226 & 184 & 56 & 91 & 93 & 154 & 172 & 197 & 199 & 112 & 207 \\
\hline $\mathrm{Ce}$ & 87 & 71 & 23 & 22 & 64 & 71 & 49 & 54 & 84 & 19 & 15 & 37 & 15 \\
\hline $\mathrm{Ba}$ & 447 & 1181 & 393 & 220 & 239 & 982 & 315 & 1600 & 1383 & 340 & 285 & 223 & 604 \\
\hline $\mathrm{La}$ & 36 & 32 & 9 & 10 & 26 & 29 & 19 & 25 & 31 & 8 & 8 & 13 & 6 \\
\hline
\end{tabular}

+ Sample for U-Pb geochronology.

* Samples analyzed at University of Rhode Island XRF Lab; all other analyses from the Ronald B. Gilmore X-ray Analytical Facility, University of Massachusetts.

$\$$ Total iron.

2007; table 1). The xenocrystic component is possibly from a source comparable to the Dedham Granite (Thompson and others, 2010; dates in table 1). A previously reported $602 \pm 3 \mathrm{Ma}$ U-Pb upper concordia intercept date from Mattapan rhyolite in Mattapan itself (Kaye and Zartman, 1980; fig. 3) is likely too old because xenocrystic components like z2 above were unavoidable in the necessarily large, multi-grain, zircon analyses carried out in such early geochronological studies (see discussion in Thompson and others, 2010).

\section{Sample MT03-09A}

Autobrecciated Brighton dacite (67.51weight $\% \mathrm{SiO}_{2}$; analysis 18 in table 2) was collected near the exposed base of the Roxbury section on Woodland Rd., Brookline, Massachusetts (fig. 3). The rock consists of quartz and partially sericitized, zoned plagioclase euhedra in a groundmass altered to chlorite, epidote, titanite and iron oxides. Accessory minerals include apatite and zircon, including prismatic grains and prism fragments chosen for U-Pb analysis. Four analyses (z2, z3, z4 and z8 in table 3) 
1016 M. D. Thompson $\mathcal{E}$ others-U-Pb zircon geochronology of Roxbury Conglomerate,

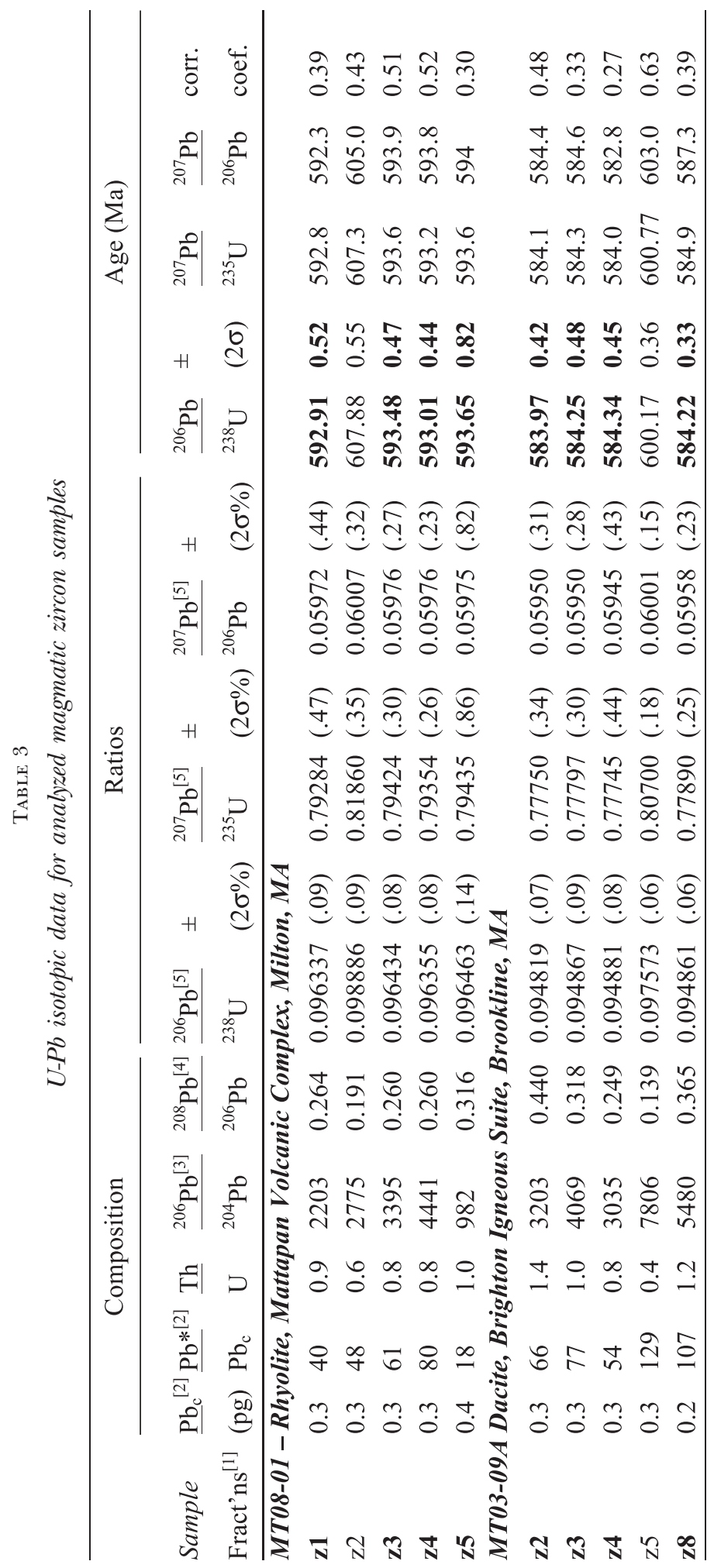




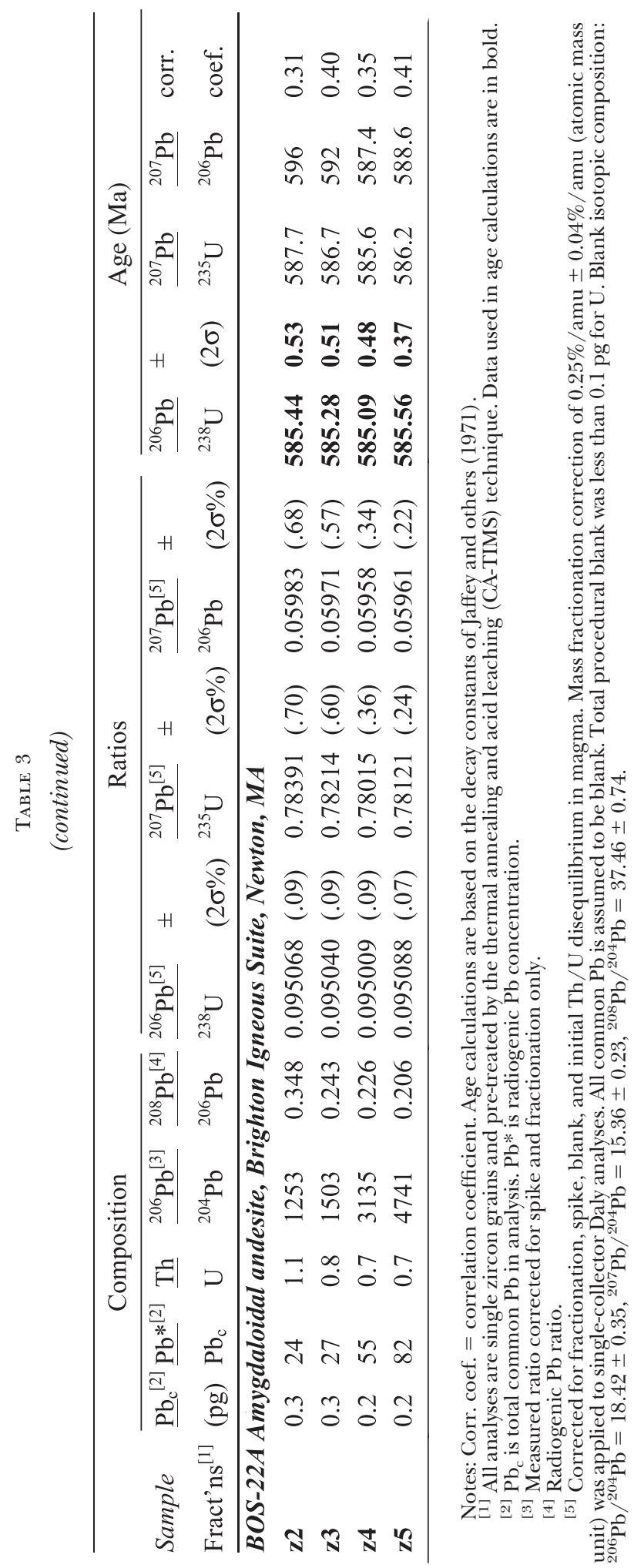


1018 M. D. Thompson $\mathcal{E}$ others-U-Pb zircon geochronology of Roxbury Conglomerate,

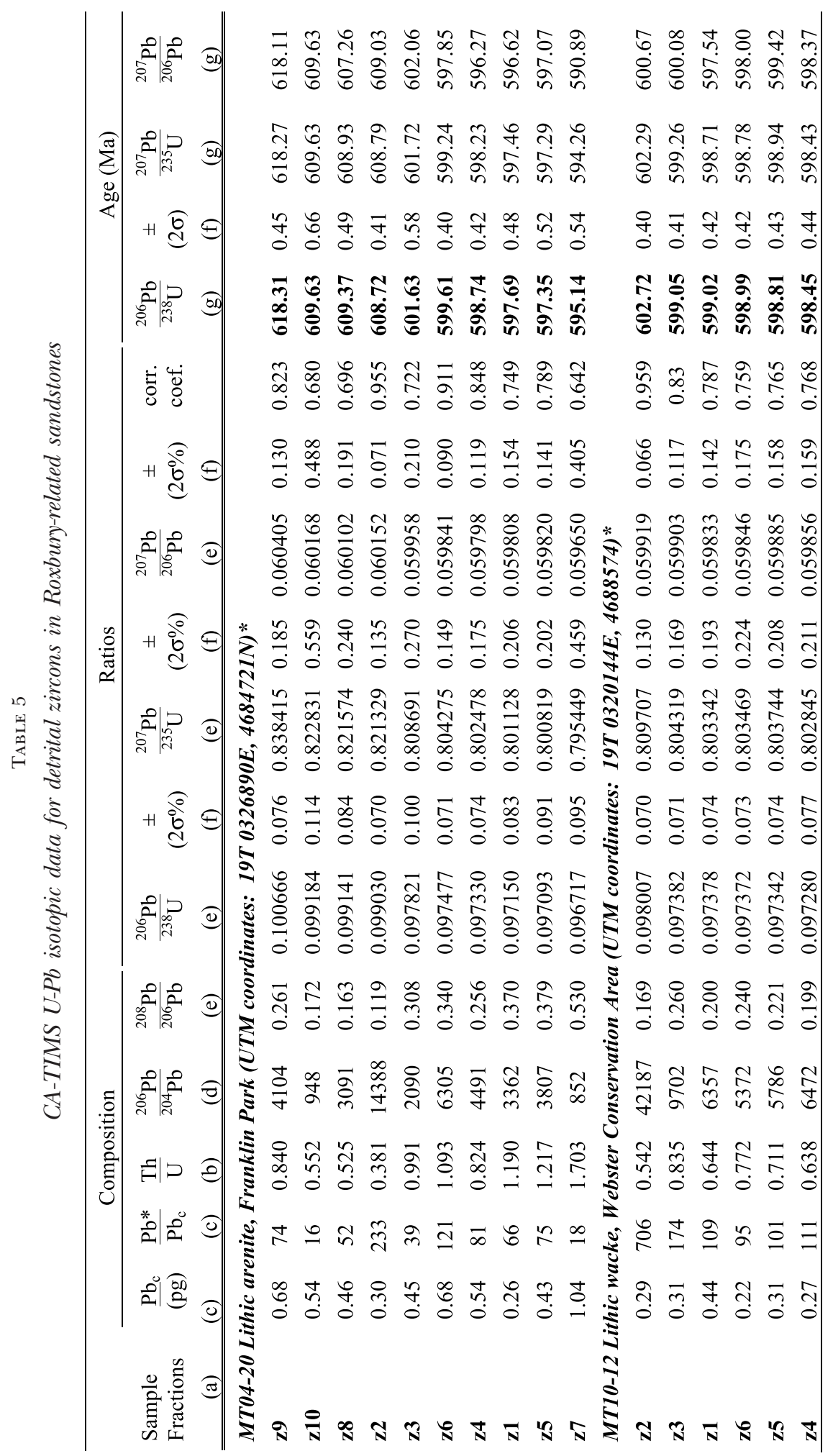




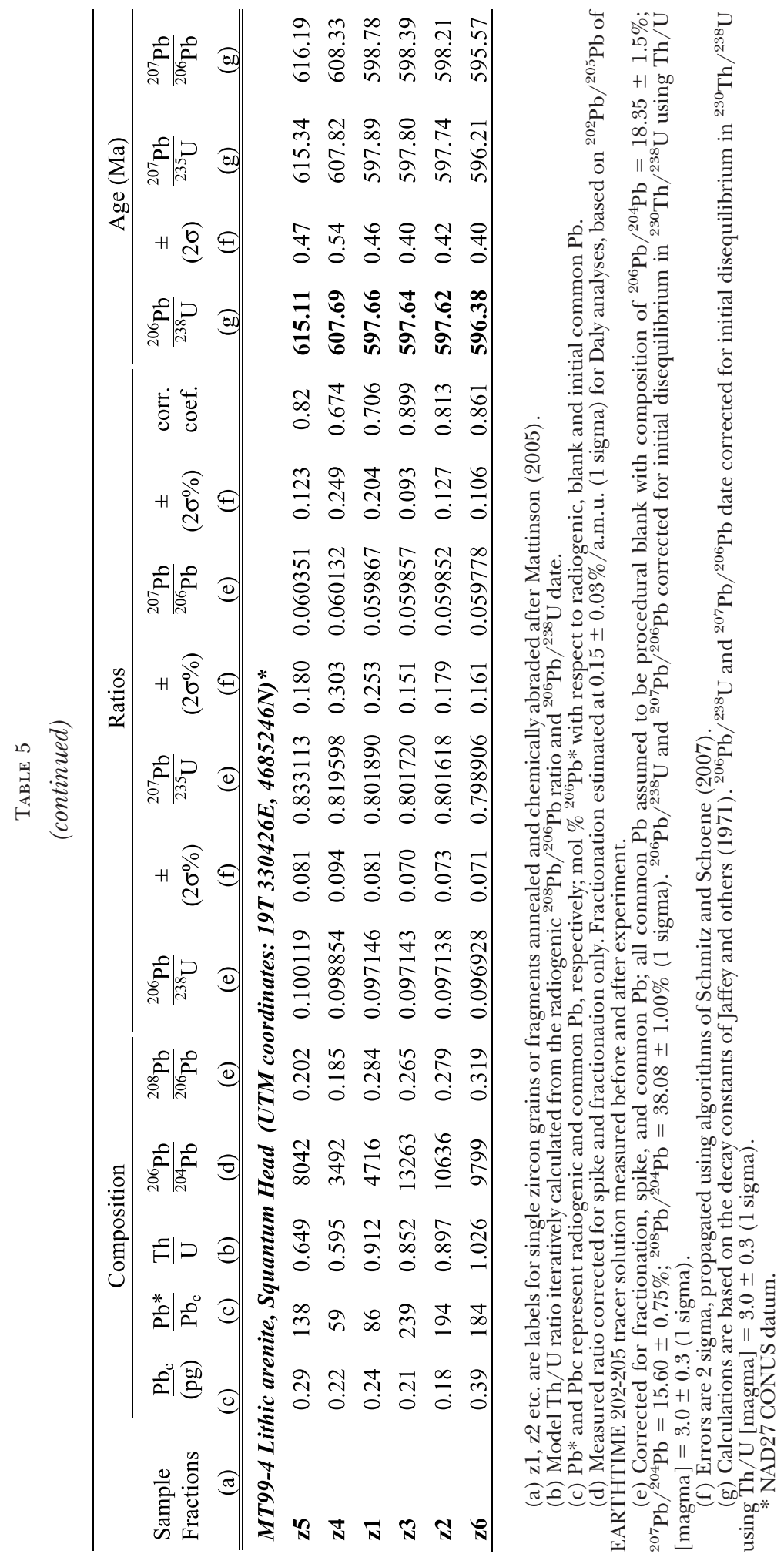


TABLE 6

Summary of $\mathrm{U}-\mathrm{Pb}$ age results and calculated errors

\begin{tabular}{|c|c|c|c|}
\hline $\begin{array}{l}\text { Sample } \\
\text { Number }\end{array}$ & Map Unit/location & ${ }^{206} \mathrm{~Pb} /{ }^{238} \mathrm{U}$ date $\pm \mathrm{X} / \mathrm{Y} / \mathrm{Z}^{1}$ & $\begin{array}{l}\mathrm{MSWD}^{2} / \\
(\mathrm{n})^{3}\end{array}$ \\
\hline MT08-01 & $\begin{array}{l}\text { Lynn-Mattapan Volcanic Complex } \\
\text { /Milton. MA }\end{array}$ & $593.19 \pm 0.26 / 0.36 / 0.73^{4}$ & $1.5 /(4)$ \\
\hline MT03-09A & Brighton Igneous Suite/Brookline, MA & $584.19 \pm 0.20 / 0.32 / 0.70^{4}$ & $0.55 /(4)$ \\
\hline BOS $22 \mathrm{~A}$ & Brighton Igneous Suite/Brighton, MA & $585.37 \pm 0.23 / 0.35 / 0.72^{4}$ & $0.84 /(4)$ \\
\hline MT04-20 & $\begin{array}{l}\text { Franklin Park Member /Roxbury } \\
\text { Conglomerate/Dorchester, MA }\end{array}$ & $595.14 \pm 0.54 / 0.66 / 0.90$ & (1) \\
\hline MT10-12 & $\begin{array}{l}\text { Brookline Member/Roxbury } \\
\text { Conglomerate/Newton, MA }\end{array}$ & $598.87 \pm 0.19 / 0.34 / 0.71^{4}$ & $1.3 /(5)$ \\
\hline MT99-4 & $\begin{array}{l}\text { Brookline Member/ Roxbury } \\
\text { Conglomerate/Quincy, MA }\end{array}$ & $596.39 \pm 0.40 / 049 / 0.79$ & (1) \\
\hline
\end{tabular}

${ }^{1}$ All errors are $2 \sigma$ and are expressed in two significant figures (details in section headed U-Pb GEOCHRONOLOGY).

${ }_{3}^{2}$ Mean square of weighted deviates.

${ }^{3}$ Number of analyses included in average.

${ }^{4}$ Weighted mean ${ }^{206} \mathrm{~Pb} /{ }^{238} \mathrm{U}$ date; other entries are analyses of single zircons.

form a statistically coherent cluster with a weighted mean ${ }^{206} \mathrm{~Pb} /{ }^{238} \mathrm{U}$ date of $584.19 \pm$ $0.70 \mathrm{Ma}(\mathrm{MSWD}=0.55)$ representing the crystallization age of the dacite (concordia plot in fig. 4B). A fifth zircon (z5 in table 3) with an older ${ }^{206} \mathrm{~Pb} /{ }^{238} \mathrm{U}$ date of $600.17 \pm$ $0.36 \mathrm{Ma}$ is interpreted to contain a xenocrystic component which is not shown in figure $4 \mathrm{~B}$.

\section{Sample BOS22A}

Amygdaloidal andesite (61.16 wt \% $\mathrm{SiO}_{2}$; analysis 20 in table 2$)$ from the Brighton Volcanic Complex was collected from the structurally highest part of the Roxbury Conglomerate on Valentine Road, Newton Center, Massachusetts (fig. 3). The rock is sparsely porphyritic with phenocrysts of albite and subordinate quartz. The groundmass contains albite laths $<0.1 \mathrm{~mm}$ to $0.5 \mathrm{~mm}$ in length along with interstitial chlorite, epidote, irregular patches of quartz and ubiquitous titanite. Vesicles are filled with various combinations of chlorite + titanite \pm epidote \pm quartz \pm Fe oxides. Accessory minerals include barite, chromite, apatite, $\mathrm{Cu}$ sulfide and zircon. Four single zircon grains were analyzed from this sample by the CA-TIMS method (z2, z3, z4, z5 in table 3 ), all of which form a statistically coherent cluster with a weighted mean ${ }^{206} \mathrm{~Pb} /{ }^{238} \mathrm{U}$ date of $585.37 \pm 0.72 \mathrm{Ma}(\mathrm{MSWD}=0.84)$ that we interpret as the crystallization age of the andesite. A concordia plot of these results appears as figure $4 \mathrm{C}$.

\section{Sample MT04-20}

This sample of dusky red, medium-grained lithic arenite comes from the south side of Franklin Park in the Dorchester section of Boston (fig. 3). It forms a horizon at the top of coarse, largely sandstone-free conglomerate that is typical elsewhere in the park and extends westward into West Roxbury, Massachusetts. The sample yielded an abundant detrital zircon suite in which rounded grains are more abundant than sharply facetted morphologies, and 91 LA-ICPMS analyses from representative grains appear in table 4 .

The principal frequency maximum in the probability density distribution lies at ca. 611 Ma and reflects contributions from 28/91 analyses (31\%). Older peaks, chiefly 

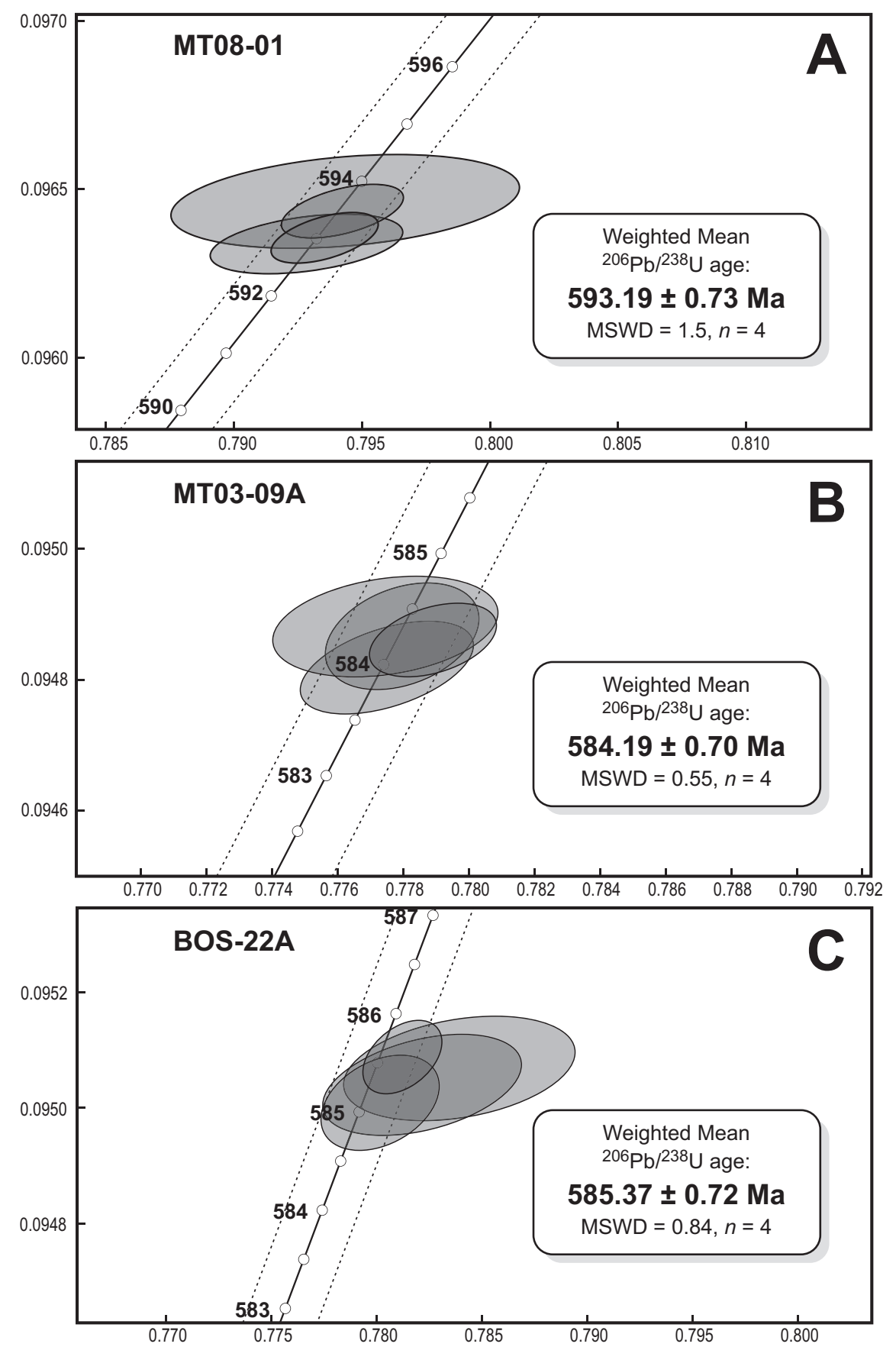

Fig. 4. U-Pb concordia plots for magmatic samples dated in this study. (A) Sample MT08-01 from Lynn-Mattapan Volcanic Complex, Milton, MA. (B) Sample MT03-09A from Brighton Igneous Suite, Brookline, MA. (C) Sample BOS22A from Brighton Igneous Suite, Newton, MA. Ages in Ma are marked on the concordia curve, and individual analyses of single zircons are shown as $2 \sigma$ error ellipses. Dashed lines mark the concordia error envelope. Errors reported as $\pm \mathrm{Z}$; complete U-Pb isotopic data and complete date errors are listed in tables 3 and 6, respectively. MSWD-mean square of weighted deviates. Sample locations in figure 3. 

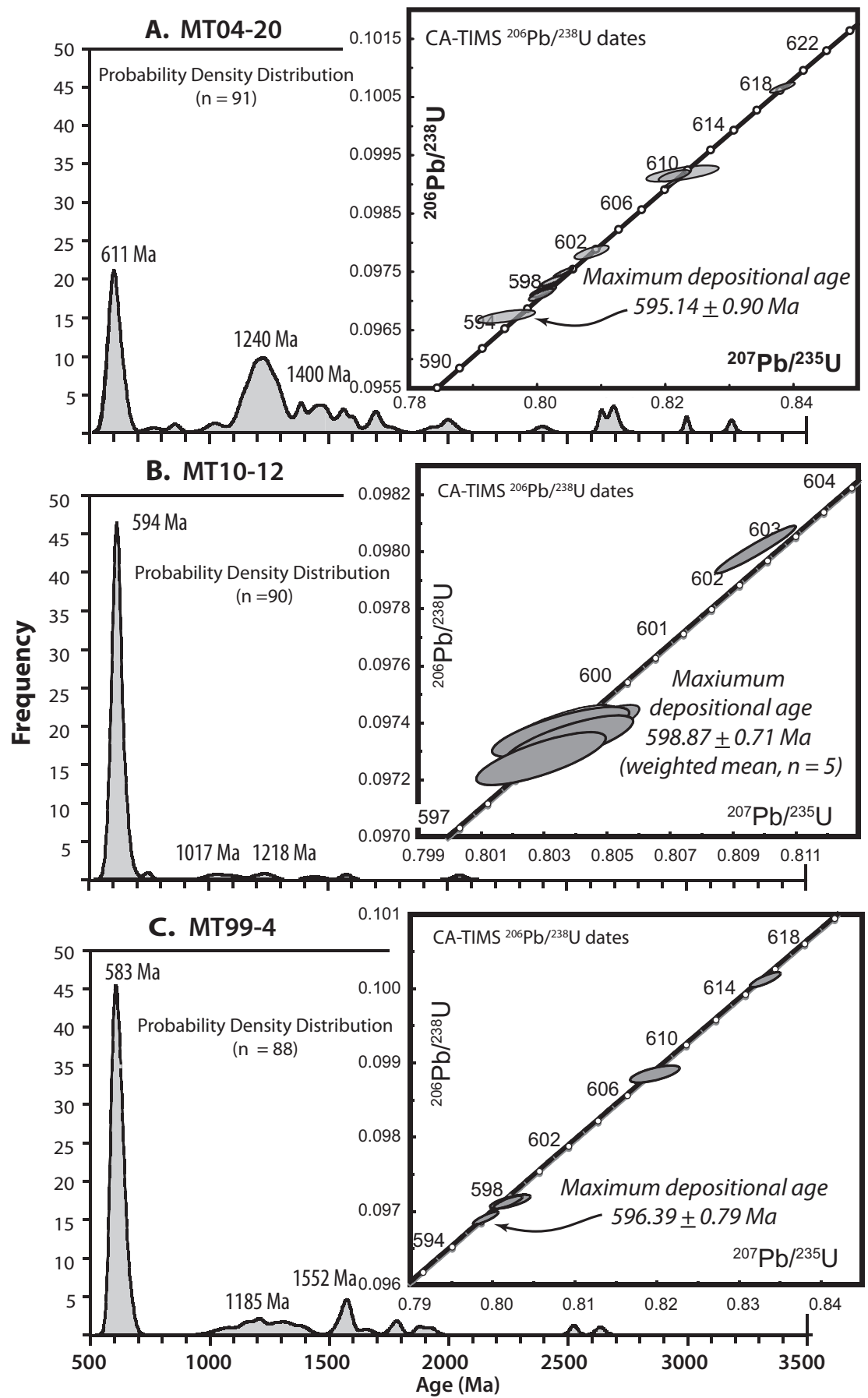

Fig. 5. Detrital zircon U-Pb geochronology of Roxbury-related sandstones in the Boston Basin. (A) Sample MT04-20 from Franklin Park, Dorchester, MA. (B) Sample MT10-12 from Webster Conservation Area, Newton, MA. (C) Sample MT99-4 from Squantum Head, Quincy, MA. Left hand side of each panel shows probability density distribution of LA-ICPMS analyses scaled to same vertical axis (AgeDisplay program of Sircombe, 2004); right hand side shows U-Pb concordia plot for CA-TIMS analyses of zircons related to the youngest probability peak. Ages in Ma are marked on the concordia curve, and individual analyses of single zircons are shown as $2 \sigma$ error ellipses. Maximum age of each sandstone based on the youngest ${ }^{206} \mathrm{~Pb} /{ }^{238} \mathrm{U}$ CA-TIMS date (errors $\pm \mathrm{Z}$ ). 
in the Mesoproterozoic range but also including Paleoproterozoic and Archean components, encompass the majority of analyses. Zircons starred in table 4 were re-analyzed via CA-TIMS to constrain the 611 Ma frequency maximum for this sample. These grains yielded concordant $\mathrm{U}-\mathrm{Pb}$ data, with ${ }^{206} \mathrm{~Pb} /{ }^{238} \mathrm{U}$ dates ranging from $618.31 \pm 0.83 \mathrm{Ma}$ to $595.14 \pm 0.90 \mathrm{Ma}$ (errors reported as $\pm \mathrm{Z}$; smaller errors in table 5 are $\pm \mathrm{X}$ ). The maximum age of the sample is thus $595.14 \pm 0.90 \mathrm{Ma}$ (concordia inset in fig. 5A), but half of the CA-TIMS analyses were $>600 \mathrm{Ma}$.

\section{Sample MT10-12}

This sample is grayish brown, coarse-grained lithic wacke from the Webster Conservation Area, Newton Massachusetts (fig. 3), a much visited field trip location in the Boston Basin (see table 1 in Thompson and Grunow, 2004). The sampled horizon immediately overlies a series of amygdaloidal basaltic flows that yielded only xenocrystic zircons in an earlier dating attempt. Several thousand detrital zircon crystals were separated from a hand sample of MT10-12. Ninety LA-ICPMS analyses from grains representing the range of morphologies in this suite are shown in table 4 and plotted as a probability density distribution in figure 5B. The dominant Ediacaran frequency maximum ( $c a .594 \mathrm{Ma}$ ) in the probability distribution reflects $81 / 90$ analyses $(90 \%)$. Nine zircons contribute to tiny, older frequency maxima scattered from Lower Neoproterozoic to Paleoproterozoic. Six zircons (starred in table 4) were re-analyzed via CA-TIMS to constrain the Ediacaran probability peak for this sample (table 5). These grains yielded concordant $\mathrm{U}-\mathrm{Pb}$ data, with a range of ${ }^{206} \mathrm{~Pb} /{ }^{238} \mathrm{U}$ dates from $602.72 \pm 0.79$ to $598.46 \pm 0.81 \mathrm{Ma}$ (errors stated here as $\pm \mathrm{Z}$ ). The five youngest grains (z1, z3, z4, z5, z6 in table 5) yielded a weighted mean ${ }^{206} \mathrm{~Pb} /{ }^{238} \mathrm{U}$ date of $598.87 \pm 0.71$ $\mathrm{Ma}(\mathrm{MSWD}=1.3)$ that is the best estimate of the maximum age for sample MT10-12 (concordia inset in fig. 5B).

\section{Sample MT99-4}

This sample is brownish-gray, medium to coarse lithic arenite immediately underlying the lonestone horizon on the western end of Squantum Head, Quincy, Massachusetts (fig. 3) that was collected for a previous study (Thompson and Bowring, 2000). The goal at that time was to establish a maximum age for the still-debated glacial deposits at Squantum, so twelve euhedral, elongate, prismatic zircons were chosen for pre-treatment by air abrasion and TIMS analysis. In the present study, all observed morphologies were sampled from several thousand zircons remaining from MT99-4 in order to capture the full range of detrital zircon ages. LA-ICPMS analyses from 88 representative grains are shown in table 4 and plotted as a probability density distribution in figure 5C. The prominent Ediacaran frequency maximum ( $c a .583 \mathrm{Ma}$ ) in the probability distribution reflects analyses from 63/88 zircons (72\%). The remaining analyses plot mostly as a cluster of small Mesoproterozoic peaks, trailing into the Upper Paleoproterozoic. Two tiny peaks in the Lower Paleoproterozoic and Archean each reflect a single analysis.

Of six re-analyzed zircons (starred in table 4), the youngest ${ }^{206} \mathrm{~Pb} /{ }^{238} \mathrm{U}$ CA-TIMS date of $596.39 \pm 0.79 \mathrm{Ma}(\mathrm{z} 6$ in table 5$)$ is the best estimate of the maximum age of this sample (error stated here and in concordia inset in fig. $5 \mathrm{C}$ as $\pm \mathrm{Z}$ ). Three others (z1, $\mathrm{z} 3$, z2, in table 5) cluster together on concordia and give a weighted mean ${ }^{206} \mathrm{~Pb} /{ }^{238} \mathrm{U}$ date of $597.65 \pm 0.72 \mathrm{Ma}(\mathrm{MSWD}=0.01)$. The other two zircons $(\mathrm{z} 4, \mathrm{z} 6$ in table 5$)$ yield slightly older ${ }^{206} \mathrm{~Pb} /{ }^{238} \mathrm{U}$ dates of $607.69 \pm 0.88 \mathrm{Ma}$ and $615.11 \pm 0.84 \mathrm{Ma}$.

All but one of the previously reported ${ }^{207} \mathrm{~Pb} /{ }^{206} \mathrm{~Pb}$ dates from MT99-4 (Thompson and Bowring, 2000) would plot with the Ediacaran frequency maximum in figure 5C. 


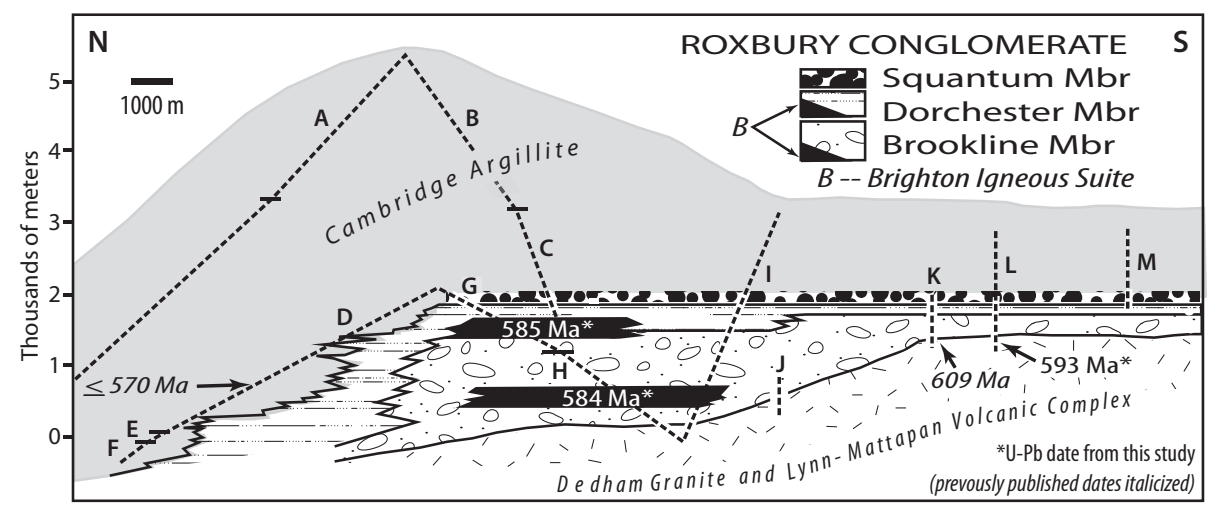

Fig. 6. Boston Basin stratigraphy based on palinspastic cross section after Billings (1976). Lettered segments show control lines from surface and tunnel mapping: (A, B)-North Metropolitan Relief Tunnel (Billing, 1975); (C)-Main Drainage Tunnel (Rahm, 1962); (D)-north part of City Tunnel Extension (Billings and Tierney, 1964); (E)-surface geology in Malden, MA; (F)-Malden Tunnel (Billings and Rahm, 1966); (G)—south part of City Tunnel Extension; (H)—surface geology, Brookline, MA; (I) — surface geology from Brookline to Dorchester, MA; (J, K)—surface geology in Mattapan, MA; (L) — surface geology, Dorchester Lower Mills, MA; (M) —surface geology, Quincy, MA. Previously published U-Pb zircon dates (in italics) for Cambridge Argillite and Dedham Granite from Thompson and Bowring (2000) and Thompson and others (2010), respectively. Types and uncertainties of dates in table 1.

DISCUSSION

\section{Revised Stratigraphy in the Boston Basin}

The currently accepted stratigraphic synthesis for the Boston Basin rests largely on subsurface relationships in the NE-trending City Tunnel Extension (CTE in fig. 3). Here, unfolded beds were interpreted to show Roxbury Conglomerate on the south and Cambridge Argillite on the north as inter-fingering lithofacies representing, respectively, proximal and distal deposits in a single depositional basin (Billings and Tierney, 1964; Billings, 1976). The transition zone is best described as inferred rather than demonstrated, however, because crucial strata linking argillite with conglomerate were not actually transected by the tunnel. Rather, Billings and Tierney sketched them under the inverted "V" representing the tunnel alignment (control lines D and G in fig. 6) after restoring beds dipping into the Charles River syncline to horizontal. In this way, Billings' (1976) palinspastic cross section tied the age of the conglomerate to the age of the argillite, so that the discovery of "Vendian" microfossils in Cambridge Argillite transected by the MBTA Red Line tunnel north of Harvard Square implied a Late Proterozoic age for both (Lenk and others, 1982). Interpolating U-Pb zircon dates presented above into Billings' schematic section reveals several problems with this picture.

First of all, not all conglomerate in and around Boston is the same age. The thin sequence overlying the Mattapan Volcanic Complex on the south side of figure 6, for example, differs lithologically from the rest of the conglomerate in figure 3 . The distinctive sequence crops out in cliffs along the Neponset River in Milton, Massachusetts (fig. 3) and is largely composed of igneous fragments both as clasts and as sand-sized matrix grains (Khoo and others, 2008). Most abundant are volcanic clasts, including basalts and rhyolites (flow banded and pyroclastic varieties) that are derived from diverse Mattapan volcanic rocks in Milton (including 593.19 \pm 0.79 Ma sample MT08-01) and in the Mattapan type locality farther upstream. Similar conglomerate in gradational contact with felsic volcanic rocks is reported to the north in the Dorchester Tunnel (DT in fig. 3; Richardson, 1977). This belt continues eastward into Hingham 
and Hull, Massachusetts (fig. 2) where volcaniclastic sedimentary rocks are interbedded with Mattapan volcanic ash that has yielded a weighted mean ${ }^{206} \mathrm{~Pb} /{ }^{238} \mathrm{U}$ date of $595.7 \pm$ 1.6 Ma (Thompson and others, 2007). The volcaniclastic conglomerate is re-interpreted here as part of the Lynn-Mattapan Volcanic Complex. Roxbury Conglomerate proper should be restricted to the central part of the Boston Basin in figure 3 and is distinguished from the Neponset Gorge Conglomerate (proposed name) by clast assemblages containing abundant quartzite (quartz arenite of Bailey and others, 1989) along with volcanic and granitoid rocks.

Brighton geochronology within the Boston Basin itself necessitates further stratigraphic revision. Dacite dated here at $584.19 \pm 0.70 \mathrm{Ma}$ lies near the base of the Roxbury Conglomerate in Brookline, Massachusetts (center of fig. 3), while $585.37 \pm$ $0.72 \mathrm{Ma}$ andesite in Newton lies much higher in the generally north-dipping section. The Brookline occurrence appears as the lower Brighton horizon in figure 6 (after Billings, 1976), and the Newton suite, which lies west of the line of section, has been projected in as the upper Brighton horizon. Finding Brighton rocks of virtually the same age at stratigraphic elevations separated by some $1000 \mathrm{~m}$ (fig. 6), most likely reflects the presence of both intrusive and extrusive members of the Brighton Igneous Suite (name adopted to replace "melaphyre" of early workers cited below).

Debate over Brighton emplacement appears in the earliest reports of Boston Basin geology, with Crosby (1880) and Woodward (unpublished work cited in Burr, 1901) arguing for successive lava flows, while others presented detailed evidence for intrusive contacts with Roxbury Conglomerate (Benton, 1881; Burr, 1901). LaForge (1932, p. 42) states, without citing specific examples, that both flows and sills are present in different places and that all are contemporaneous with Roxbury sedimentation. Billings and Tierney (1964, p. 115) repeated LaForge's conclusion in their introduction, then went on to emphasize (p. 136) that Brighton contact relationships in and around the southern segment of the City Tunnel Extension (fig. 3; control line G in fig. 7) are all intrusive. According to Tierney and others (1968, p. 76-77), Brighton occurrences in the western end of the City Tunnel (CT in fig. 3) could be one or more concordant sheets of either extrusive or shallow intrusive rocks. By contrast, Billings (1976, p. 10) describes the Brookline occurrences as bedded breccias, tuffs and flows (and perhaps for this reason included only these in his original version of fig. 6). For purposes of interpreting our Brighton dates, it is also important to consider some earlier observations of the same area in another account. Burr (1901; p. 56) described intrusive relationships in two trenches where "melaphyr" could be seen cutting moderately north-dipping conglomerate along a vertical contact, and he interpreted this intrusion as an offshoot from the main Brighton body to the south where we collected sample MT03-09A (fig. 3). An intrusive origin would most simply explain why this sample and stratigraphically higher BOS22A yield such similar dates. The bedded sequence highlighted by Billings in this area could either be Brighton extrusives (as currently shown in fig. 3), or part of the Lynn-Mattapan Volcanic Complex which includes both mafic units and 597.4 \pm 1.5 Ma rhyolite porphyry in exposures located a few $\mathrm{km}$ to the west $\left({ }^{207} \mathrm{~Pb} /{ }^{206} \mathrm{~Pb}\right.$ date of Thompson and others, 2007).

Although the Brighton emplacement issue is unlikely ever to be resolved in every instance, the dates from samples discussed above suffice to contradict the traditional interpretation of Roxbury conglomerates inter-fingering into Cambridge Argillite on the north. The $584.19 \pm 0.70 \mathrm{Ma}$ Brighton horizon occurs at approximately the same stratigraphic level as $\leq 570$ Ma volcanic ash (Thompson and Bowring, 2000) also interpolated into figure 6 and, if intrusive, would make the conglomerate $>584 \mathrm{Ma}$. Cambridge Argillite at the same stratigraphic level as the upper Brighton sequence must be younger than $\leq 570 \mathrm{Ma}$. Conglomerate in this part of the section would be $585.37 \pm 0.72 \mathrm{Ma}$ if the Brighton sequence is extrusive, or $>585 \mathrm{Ma}$ if the Brighton is 


\section{B. BROOKLINE-DORCHESTER-SQUANTUM PHASE OF ROXBURY DEPOSITION}

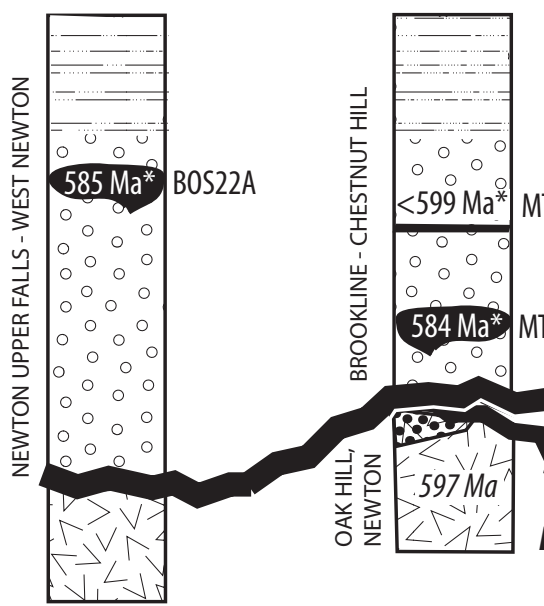

\section{ROXBURY CONGLOMERATE

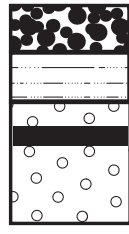 \\ Squantum Mbr Dorchester Mbr Brighton Suite Brookline Mbr $\triangle 100$ clast count

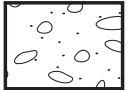 \\ Franklin Park Mbr A 100 clast count}

*U-Pb date from this study (prevously published dates italicized)

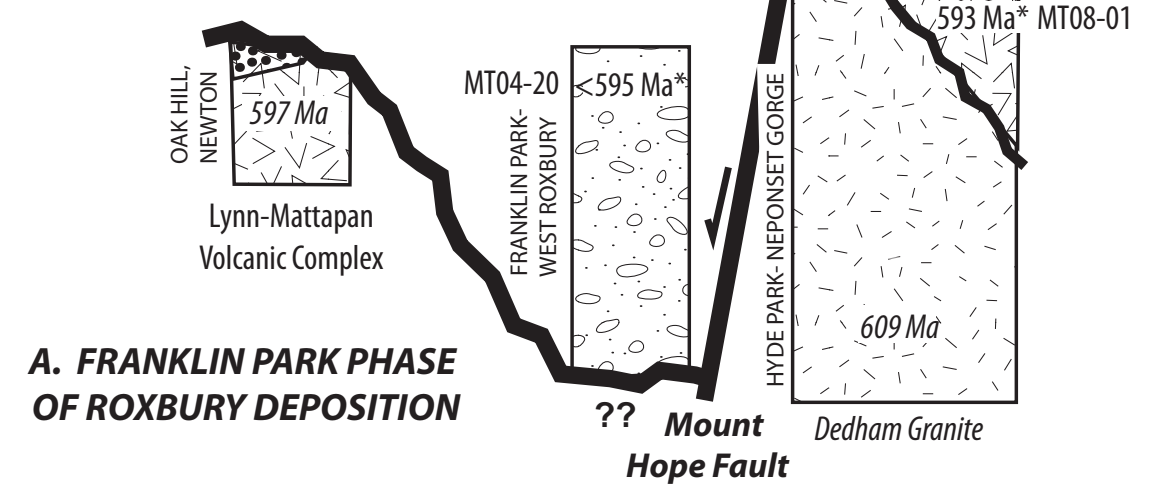

\section{A. FRANKLIN PARK PHASE OF ROXBURY DEPOSITION}

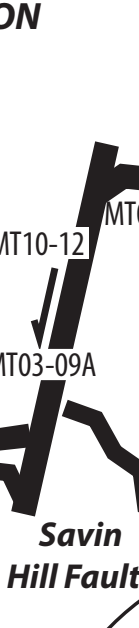

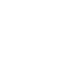

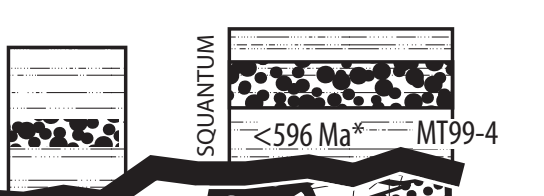

MT04-20<595 Ma**
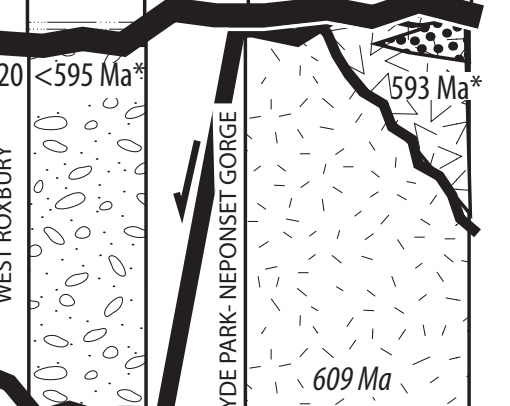

Quartzite + Granite
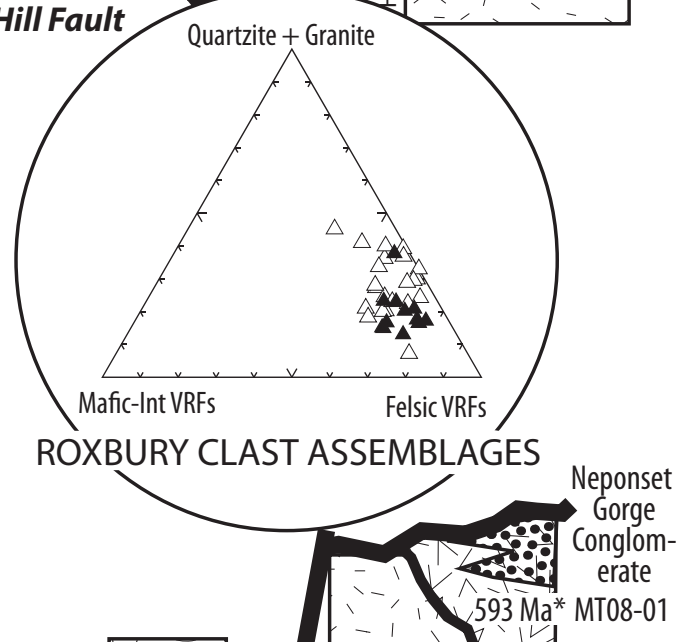

Fig. 7. Conceptual cross section showing two-phase Roxbury Conglomerate sedimentation in the Boston Basin controlled by syn-depositional normal faults. (A) Franklin Park phase of deposition controlled by Mount Hope Fault. (B) Brookline-Dorchester-Squantum phase of deposition controlled by Savin Hill Fault. Circular inset shows distinctive clast assemblages in successive conglomerates. U-Pb zircon dates accompanied by sample numbers are from this study; previously published dates (in italics) for LynnMattapan Volcanic Complex and Dedham Granite and are respectively from Thompson and others (2007 and 2010). 
intrusive. In none of these cases can conglomerate be age-equivalent facies of argillite in the northern part of the Boston Basin. Finally, as discussed further below, contrasting age distributions in detrital zircon assemblages of Roxbury-related sandstones in three sampling localities across the Boston Basin are difficult to explain in terms of a simple facies change in progressively northward-fining conglomerate.

\section{Sources of Detrital Zircon}

Pronounced Ediacaran peaks in the probability density distributions for detrital zircon suites in three Roxbury-related sandstones (fig. 5), together with euhedral morphologies of individual grains selected for follow-up CA-TIMS analysis (concordia insets in fig. 5), might suggest admixtures of volcanic ash close to the true depositional age of these sandstones. This possibility, however, runs counter to stratigraphic relations in the vicinity of Chestnut Hill (fig. 3) where the sequence containing sample MT10-12 with five zircons between $598.45 \pm 0.81$ and $599.05 \pm 0.79$ (table 5 ; $\pm \mathrm{Z}$ errors) overlies $597.4 \pm 1.5 \mathrm{Ma}$ Lynn-Mattapan volcanic rocks. As already stated, the CA-TIMS dates from the youngest zircons in the three sandstones (fig. 5) are thus maximum depositional ages, and sources for this detritus may be sought in preRoxbury granitoids (including gneissic rocks) and associated volcanics comprising basement across most of southeastern New England (fig. 2). Ages of these basement units are listed in table 1. Two zircons in the present data set yielded dates of $c a$. $615.11 \pm 0.84 \mathrm{Ma}$ and $618.31 \pm 0.83 \mathrm{Ma}(\mathrm{z} 5$ of MT99-4 and $\mathrm{z} 9$ of MT04-20 in table $5 ; \pm$ $\mathrm{Z}$ errors), suggesting that there may be units pre-dating the Dedham Granite, currently the oldest documented Ediacaran pluton (Thompson and others, 2010). These observations are also consistent with previously reported ${ }^{207} \mathrm{~Pb} /{ }^{206} \mathrm{~Pb}$ TIMS dates from MT99-4 (Z2-Z12 in table 2 of Thompson and Bowring, 2000).

The LA-ICPMS results plotted in figures 5A, 5B and 5C show contrasting detrital zircon profiles in Roxbury sandstones that are difficult to explain in terms of the northward-fining facies model. The Webster and Squantum age distributions are strongly dominated by Ediacaran peaks, and 9 of 12 CA-TIMS dates from grains contributing to these peaks are $<600 \mathrm{Ma}$ (table 5). In contrast, the Franklin Park profile contains mostly pre-Ediacaran zircons, and 5 of 10 Edicaran zircons from its correspondingly smaller Ediacaran peak yielded CA-TIMS dates $>600 \mathrm{Ma}$ (table 5). Roxbury Conglomerate deposition is better conceptualized in terms of localized depocenters controlled by successive Edicaran normal faults and supplied by different source rocks over time.

\section{Proposed Framework for Conglomerate Deposition}

A structural and stratigraphic evolution that is consistent with Roxbury and Brighton U-Pb geochronology, as well as the first author's field mapping in and around the Boston Basin, is shown schematically in figure 7. The collective observations strengthen the previous argument for Boston Basin development in conjunction with syndepositional movements on Ediacaran normal faults as argued in an earlier paper (Thompson, 1993) before isotopic age constraints became available.

In the proposed scenario, the earliest Roxbury Conglomerate (fig. 7A) accumulated in a trough bounded on the south by the Mount Hope Fault (fig. 3; also Billings, 1929 and 1976). The footwall block of the Mount Hope fault uplifts $609.1 \pm 1.1 \mathrm{Ma}$ Dedham Granite $\left({ }^{206} \mathrm{~Pb} /{ }^{238} \mathrm{U}\right.$ date of Thompson and others, 2010$)$ and the unconformably overlying Lynn-Mattapan Volcanic Complex, including 593.19 \pm 0.73 Ma rhyolite (Sample MT08-01) and associated Neponset Gorge Conglomerate. East of the map area in Hingham, Massachusetts, relief on the same unconformity is estimated as approximately $200 \mathrm{~m}$ (Billings and others, 1939). Roxbury Conglomerate in the basin north of the footwall block generally lacks sandy interbeds and contains coarse clasts locally reaching 20 to $30 \mathrm{~cm}$ (Crosby, 1880; Thompson and Grunow, 2004). Volcanic 
rocks including volcaniclastic sediments of Lynn-Mattapan origin dominate the clast assemblage (fig. 7 inset modified from Thompson, 1993), though granite and quartzite are typically present among the largest clasts. The detrital zircon assemblage in the Franklin Park sandstone at the top of this sequence, with its preponderance of pre-Ediacaran grains is consistent with detritus supplied by progressive erosion through the Lynn-Mattapan suite into underlying Dedham Granite and older rocks (Westboro Fm, Blackstone Group in fig. 3). This sequence has long been grouped with the Brookline Member of the Roxbury Conglomerate (Crosby, 1880; Emerson, 1917; Billings, 1976) but is differentiated here as the Franklin Park Member.

The Brookline name is retained for conglomerate in the northern portion of the Boston Basin (fig. 3) that is interpreted in terms of a second phase of sedimentation linked in figure 7B with activation of the Savin Hill Fault (fig. 3 and LaForge, 1932). The footwall block in this case includes previously deposited Franklin Park conglomerate as well as exposed basement units to the south. Conglomerate accumulated above the Lynn-Mattapan Complex (including Neponset Gorge Conglomerate in Jamaica Plain area of fig. 3) forming the top of the downthrown block. The Brookline name is appropriate for these younger conglomerates because they underlie all but the southernmost portion of the town of Brookline.

Distinctive features of the restricted Brookline conglomerate include generally smaller clasts and clast assemblages typically containing slightly higher proportions of quartzite and granite than Franklin Park conglomerate (fig. 7 inset). Other contrasts between the Franklin Park and Brookline sequences include more abundant sandy interbeds (Crosby, 1880; Billings, 1976; Thompson and Grunow, 2004) that yield detrital zircon suites with only minor pre-Ediacaran components. Five zircons related to the prominent Ediacaran probability peak for Webster sandstone (598.87 \pm 0.71 weighted mean ${ }^{206} \mathrm{~Pb} /{ }^{238} \mathrm{U}$ date in fig. $5 \mathrm{~B}$ ) suggest sources in granites post-dating the Dedham (Westwood, Cohasset, Esmond Granite in table 1 and fig. 2). Pre-Ediacaran components in the Squantum sandstone (fig. 5C) located higher in the section appear as a more subdued version of the Franklin Park distribution (fig. 5A) and could reflect recycled zircons from the earlier deposits (compare figs. 5A and 5C). Most important, Brighton igneous rocks occur at various levels in the Brookline section. The horizon immediately below sample MT10-12 in figure 7B is clearly a series of flows with amygdaloidal tops that shed clasts into the overlying sandstone. Both dated horizons, as previously described, are treated as intrusive. Younger strata comprising the Dorchester and Squantum members in the classic Roxbury stratigraphy blanket the entire region, overlying both conglomerate sequences as well as the Mount Hope footwall block.

The two-phase depositional scenario is highlighted in the map pattern of figure 3 by darker shading for the proposed Franklin Park Member in the southern trough. The Dorchester-Squantum sequence is interpreted to have buried the trace of the Mount Hope Fault (fig. 7B) before being cut by a younger high angle fault in the southeast corner of map (fig. 3). Dorchester-Squantum deposits similarly bury the eastern end of the Savin Hill fault in the Newton sector, but here also later NNEtrending cross faults obscure this relationship. Upper members of the Roxbury Conglomerate overlie the Brookline Member in the north and the Franklin Park Member on the south, but sedimentation was continuous only in the north (as demonstrated in the subsurface section in the Main Drainage Tunnel; Rahm, 1962; MDT in fig. 3). In the southern trough, the higher members rest without obvious discordance on the erosion surface truncating coarse Franklin Park conglomerate (fig. 7B). The contact between the Franklin Park sequence and higher Brookline strata in the east central portion of figure 2 is therefore a disconformity. Fault block topography appears to have disappeared by the time of Cambridge Argillite deposition because 
this sequence is thickly developed across the entire map area and eastward into Boston Harbor as well (Rahm, 1962; Billings, 1975; Thompson and others, 2012). The $\leq 570$ Ma age constraint on the Cambridge comes from low in the section (fig. 7), implying a ca. 15 Ma age gap with underlying Roxbury Conglomerate and making this contact an unconformity.

\section{Tectono-stratigraphic Implications for Avalonia In and Beyond SE New England}

In a widely quoted synthesis of Avalonian tectonic history, subduction lasting as late as $570 \mathrm{Ma}$ overlapped the onset of bimodal magmatism starting as early as $590 \mathrm{Ma}$ that ushered in a phase of intra-continental rifting (Nance and Murphy, 1996; Murphy and others, 1999, 2004; Nance and others, 2008). This transition is recorded in a conflicting variety of tectonic activity around Avalonia in the 590 to $570 \mathrm{Ma}$ interval. Placing southeastern New England within this scenario has been difficult because of the spotty and imprecise U-Pb geochronology available when the synthesis first appeared. Recently published U-Pb zircon dates based exclusively on single grain analyses (Thompson and others, 2007; Thompson and others, 2010) together with constraints presented here from the Boston Basin now allow revisions to the existing synthesis and suggest hitherto unexplored relationships as well.

The cessation of main phase arc magmatism in southeastern New England has previously been linked to $595 \pm 5$ Ma alkalic rocks comprising early intrusives of the small Dartmouth Pluton near New Bedford, Massachusetts (D in fig. 2). This concordia upper intercept date based on six discordant analyses of multi-grain zircon fractions (Hermes and Zartman, 1992), however, is probably too old for the same reasons discussed with respect to the Mattapan result of Kaye and Zartman (1980). A transition age younger than $595 \mathrm{Ma}$ is all the more probable in the face of regionally more extensive Lynn-Mattapan volcanic rocks that formed at the same time (fig. 2; table 1). Lynn-Mattapan samples range from basalt to rhyolite (fig. 8A) collectively showing a calc-alkaline evolution trend (fig. 8B), and basalts within the suite yield trace element signatures indicating volcanic arc settings (figs. 8C and 8D). Minor calc-alkaline plutonism younger than $595 \mathrm{Ma}$ is recorded in $589 \pm 2 \mathrm{Ma}$ quartz diorite near Westwood, Massachusetts (upper concordia intercept date of Thompson and others, 1996; figs. 3, 8A and 8B). The Brighton Igneous Suite within the Roxbury Conglomerate shows compositions that overlap but are slightly more restricted than the LynnMattapan range (basalt to rhyodacite in fig. 8A), with basalts also plotting in the volcanic arc fields of trace element discrimination diagrams (figs. 8C and 8D). Brighton magmatism in the 585 to $584 \mathrm{Ma}$ interval thus represents the final phase of episodic Avalonian arc activity that began around $610 \mathrm{Ma}$ with multiple pulses of granitoid plutonism (Thompson and others, 2010). These findings are consistent with the previous interpretation of the Roxbury-Brighton assemblage as rift-related deposits filling an intra-arc basin (Thompson, 1993) rather than rift or wrench basins postdating main phase Avalonian subduction (Murphy and Nance, 1989, for example).

Post-Roxbury sedimentation produced submarine fan and slope-related turbiditic mudstones and siltstones of the Cambridge Argillite at the top of the Boston Bay Group (Socci and Smith, 1990; Smith and Socci, 1990; fig. 9A), with thickness reaching $5700 \mathrm{~m}$ in the northern part of the Boston Basin (Billings, 1976) and bulk compositions indicating a significant component of volcanic ash (Thompson and Bowring, 2000). These deposits have long been compared (Murphy and Nance, 1989) with volcaniclastic turbidite sequences found in the Jeffers and Georgeville groups, respectively in the Cobequid and Antigonish highlands of northern mainland Nova Scotia (Cob, A in fig. 1; Pe-Piper and Piper, 1989, 2002; Murphy and others, 1992) and in the Connecting Point and Conception groups, respectively in the Bonavista and Avalon peninsulas of Newfoundland (Bv, Av in fig. 1; Williams and King, 1976, 1979; Gardiner and Hiscott, 1988; Dec and others, 1992). All of these have been interpreted as 


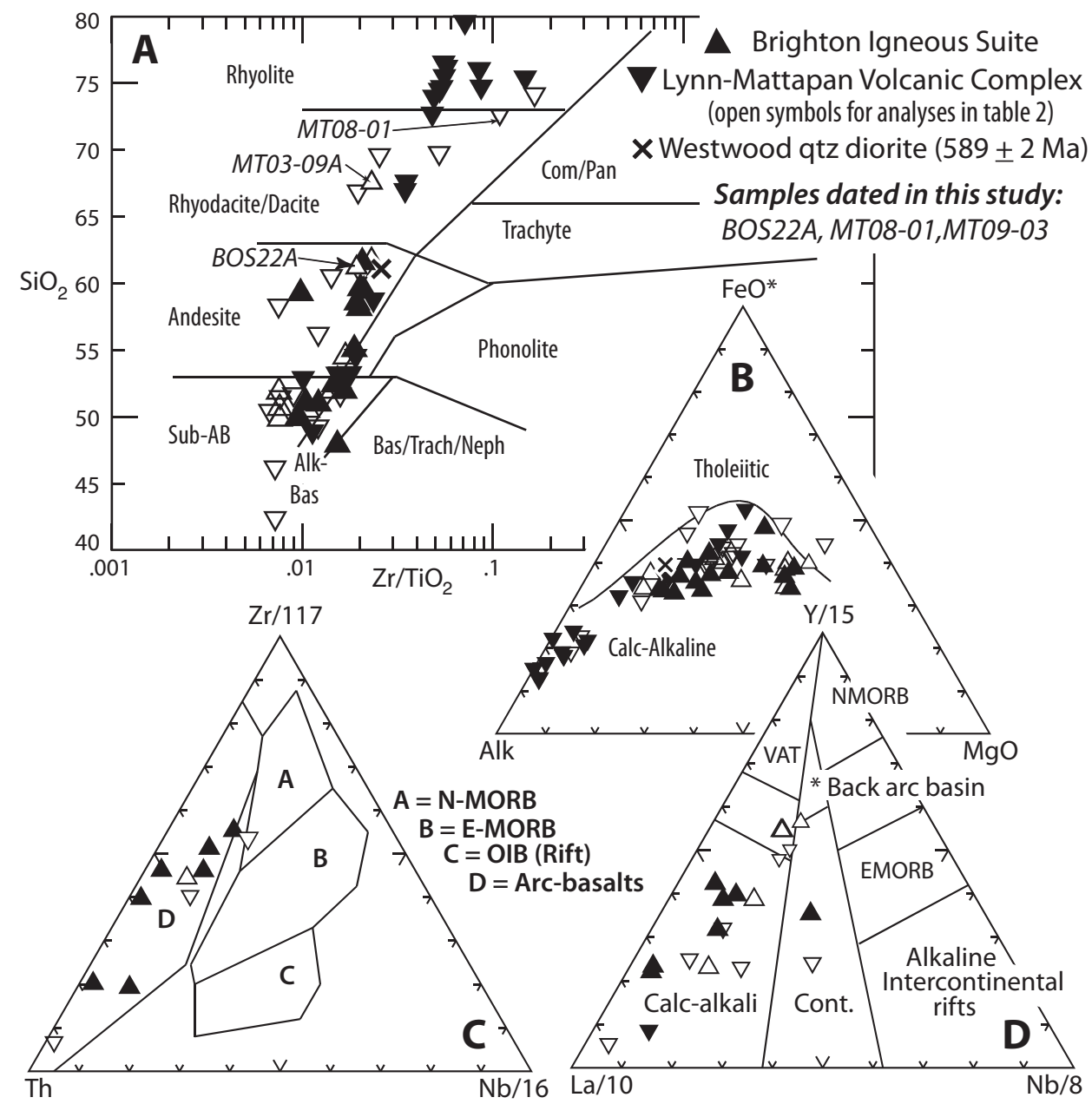

Fig. 8. Geochemical characteristics of 597-593 Ma Lynn-Mattapan Volcanic Complex and 585-584 Ma Brighton Igneous Suite in and around the Boston Basin. Plotted data include analyses in table 2 and previously published analyses from Cardoza and others (1990), Thompson and Hermes (1990), Thompson (1993), Thompson and others $(1996,2007)$. (A) $\mathrm{Zr} / \mathrm{TiO}_{2}$ plot of Winchester and Floyd (1977); (B) AFM plot of Irvine and Baragar (1971); (C) Th-Zr/117-Nb/16 plot of Wood (1980) showing only basaltic analyses in sources above; (D) La/10-Y/15-Nb/8 plot of Cabanis and Lecolle (1989) likewise showing only basaltic analyses.

deposits in various intra-arc, inter-arc and back arc basins (Murphy and Nance, 1989; Nance and Murphy, 1996; Murphy and others, 1999, 2004; Nance and others, 2008). The $<617.7 \pm 1.6$ Ma Georgeville and $<628.5 \pm 2.6$ Ma Jeffers sequences are most convincingly linked with this tectono-stratigraphic setting because their respective $606.6 \pm 1.6 \mathrm{Ma}$ and $603+9 /-5 \mathrm{Ma}$ minimum ages come from arc-related plutons (figs. 9B and 9C; U-Pb concordia upper intercept dates of Murphy and others, 1997). Younger, presumably diachronous equivalents (recent review in Nance and others, 2008 ) include the Connecting Point Group with a 610 Ma volcanic ash bed halfway up its 4 to $5 \mathrm{~km}$ thick section (fig. 9D; U-Pb zircon date of G. R. Dunning reported without uncertainties in Dec and others, 1992), but the duration of this sedimentation is only loosely bracketed as older than $c a$. 570 Ma Bull Arm volcanic rocks within the 


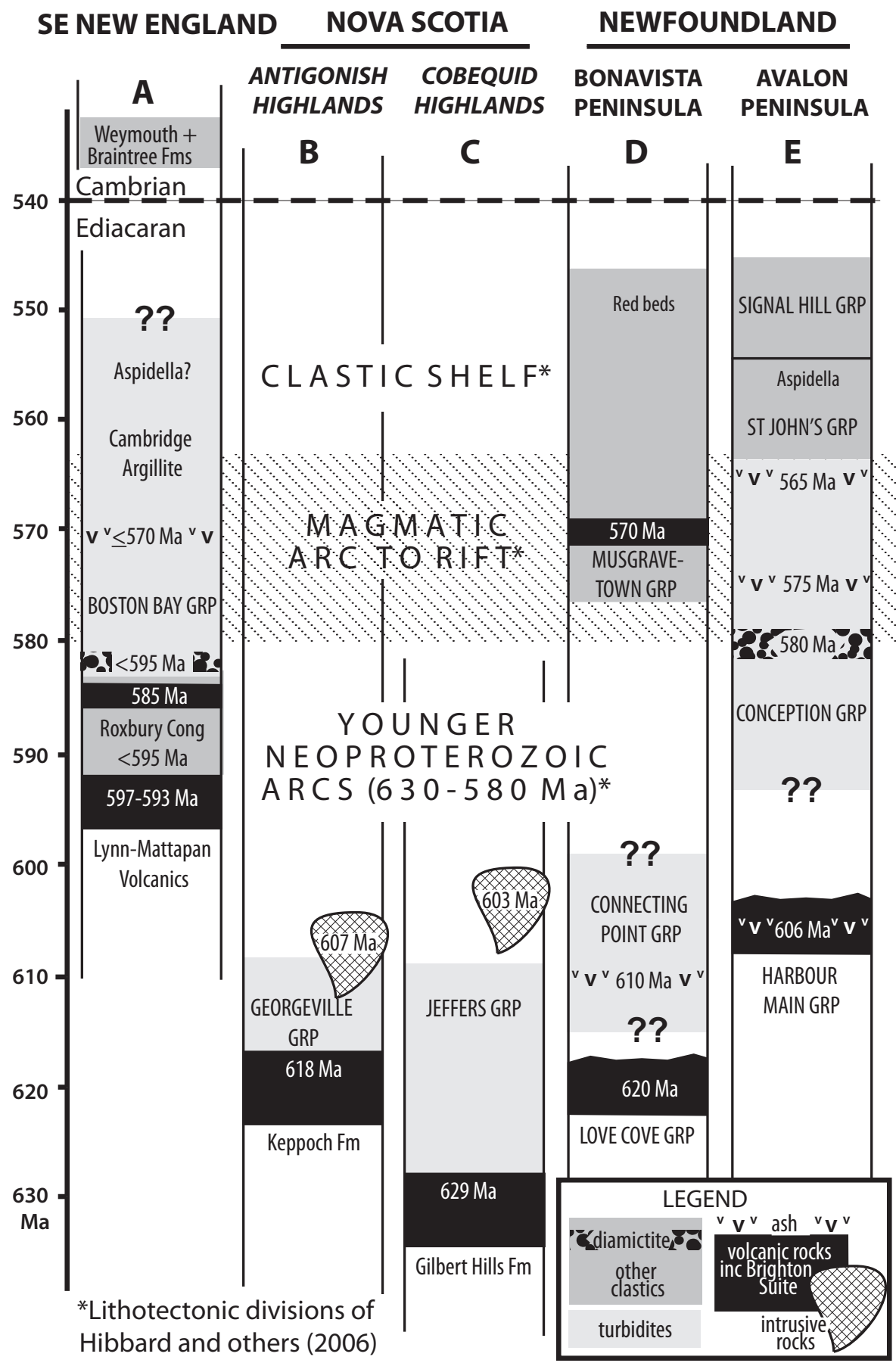

Fig. 9. Tectono-stratigraphic comparison between Ediacaran sequence in Boston Basin sector of Avalonia in southeastern New England and selected Avalonian terranes in Nova Scotia and Newfoundland. Types, uncertainties and sources of dates outside of New England are referenced in text. 
unconformably overlying Musgravetown Group (Jenness, 1963; O’Brien and others, 1996) discussed further below. The Conception Group unconformably overlies 606 +3.7/-2.9 Ma Harbour Main Volcanics (Rose, 1952; McCartney 1967; upper concordia intercept U-Pb zircon date of Krogh and others, 1988), but passes upward into demonstrably younger turbidites that include volcanic ash beds above and below the Gaskiers Formation approximately $800 \mathrm{~m}$ above the base of the section (fig. 9E). These beds have yielded zircon dated as $580 \mathrm{Ma}$, and zircon from an ash bed in the overlying Drook Formation is $575 \mathrm{Ma}$ (unpublished U-Pb data of Bowring and others, 2003 reported without uncertainties). The Mistaken Point Formation at the top of the Avalon Peninsula section with its spectacular Ediacaran fossil assemblage (Williams and King, 1976; Anderson, 1978; Conway Morris, 1989; Jenkins, 1992) contains $565 \mathrm{Ma}$ volcanic ash (U-Pb zircon date of G. R. Dunning in Benus, 1988; uncertainties not included).

The Cambridge Argillite, constrained as $\leq 570$ Ma by a volcanic ash bed in Somerville, Massachusetts (fig. 3; Thompson and Bowring, 2000), overlaps in age with both the Musgravetown Group and the Conception Group in figures 9A, 9C and 9D, a pattern that reveals some inconsistencies in relationships portrayed in the lithotectonic map of Hibbard and others (2006). Here, the Musgravetown Group is shown as part of the transition sequence between older magmatic rocks and younger clastic shelf deposits (map unit 19), while the Conception Group appears among components of 630 to $580 \mathrm{Ma}$ Neoproterozoic arcs (map unit 20). These relationships are re-assessed below.

The Musgravetown Group contains thick conglomerate at the base overlain by volcanic rocks (Cannings Cove Formation and Bull Arm Formation of Jenness, 1963) nominally corresponding to Roxbury Conglomerate and associated Brighton suite beneath the Cambridge Argillite (figs. 9A and 9D), and perhaps for this reason, the Boston Bay Group and Musgravetown Group are listed together in the Avalonian arc to rift transition (unit 20 of Hibbard and others, 2006). Yet the 585 to 584 Ma Brighton constraints indicate that the Roxbury section is significantly older than $570+3 /-2 \mathrm{Ma}$ Bull Arm volcanics (unpublished upper intercept U-Pb zircon date of G. R. Dunning), and the bimodal, alkalic character of the Bull Arm suite (O'Brien and others, 1996) contrasts distinctly with the calc-alkaline Brighton assemblage documented above. Rather, the Roxbury-Brighton age constraint on the Boston Bay Group strengthens previously suggested parallels with the Conception Group (Thompson and Bowring, 2000). In particular, Squantum glaciomarine strata at the top of the Roxbury Conglomerate (Dott, 1961; Socci and Smith, 1990; Smith and Socci, 1990) lie above 585.37 \pm $0.72 \mathrm{Ma}$ Brighton intrusions lower in the section, and may be closer in age than can be established by 599 to 595 Ma maximum depositional ages (fig. 5) to $580 \mathrm{Ma}$ glacial diamictites in the Gaskiers Formation (Brueckner and Anderson, 1971; Anderson and King, 1981; Eyles and Eyles, 1989; Myrow and Kaufman, 1999; unpublished U-Pb data of Bowring and others, 2003). Also, strata assigned to the Cambridge Argillite in Hingham, Massachusetts and outer islands in Boston Harbor (fig. 2) contain discshaped fossils (described by Bailey in Thompson and Bailey, 1998; Bailey and Fletcher, 2002; Thompson and others, 2012) that are possible counterparts of Aspidella terranovica Billings, 1872 which is especially abundant in the $1400 \mathrm{~m}$ thick Fermeuse Formation of the St. John's Group overlying the Conception Group (Hofmann and others, 1979; Conway Morris, 1989; Gehling and others, 2000; figs. 9A and 9E). Lithotectonically, the St. John's Group, consisting of upward shoaling deltaic deposits (Williams and King, 1979; Gehling and others, 2000), is part of the clastic shelf sequence marking the end of the Avalonian tectonic cycle (unit 21 of Hibbard and others, 2006). From this perspective, both the Conception Group and Cambridge Argillite portion of the Boston Bay Group seem better viewed as transitional sequences. 
The absence of local volcanism at the time of post-580 Ma ash beds in higher parts of both successions is also consistent with this interpretation.

Possible sources for post-580 Ma volcanic ashes in the Boston Bay and Conception groups are found in other segments of Avalonia that remained volcanically active during the arc-to-platform transition interval. Continuing subduction in the Mira terrane of Cape Breton Island, Nova Scotia (fig. 1), for example, produced calcalkaline to tholeiitic assemblages of the $575+4 /-1$ Ma Fourchu Group and $\leq 563 \pm 2$ Ma Main-à-Dieu Group (respectively, upper intercept and ${ }^{206} \mathrm{~Pb} /{ }^{238} \mathrm{U}$ dates in Bevier and others, 1993), as well as minor associated plutons (Barr and White, 1996; Barr and others, 1996). Ash-producing volcanism is also documented in the previously mentioned $c a .570$ Ma Bull Arm bimodal basalt-rhyolite flows and associated pyroclastic deposits of the Musgravetown Group (Jenness, 1963; O’Brien and others, 1996) and in the more voluminous 560 to 550 Ma Coldbrook Group in southern New Brunswick (Cal in fig. 1; Barr and White, 1988, 1996; ${ }^{207} \mathrm{~Pb} /{ }^{206} \mathrm{~Pb}$ dates in Bevier and Barr, 1990; Barr and others, 1994).

\section{CONCLUSIONS}

Roxbury Conglomerate in the Boston Basin sector of Avalonia in southeastern New England has been dated using a combination of U-Pb isotopic techniques. Zircons contributing to the youngest peak in probability density distributions of LA-ICPMS analyses from detrital suites in three Roxbury-related sandstones were re-analyzed via CA-TIMS to obtain precise ${ }^{206} \mathrm{~Pb} /{ }^{238} \mathrm{U}$ dates. These establish respective maximum depositional ages of $595.14 \pm 0.90 \mathrm{Ma}, 598.87 \pm 0.71 \mathrm{Ma}$ and $596.39 \mathrm{Ma} \pm 0.79 \mathrm{Ma}( \pm$ $\mathrm{Z}$ errors in summary table 6) for samples representing, in ascending order, the Franklin Park Member (proposed name), the Brookline Member and the Squantum Member. The youngest of these is the best maximum age estimate for the entire Roxbury section. Also associated with Roxbury Conglomerate are fine-grained igneous rocks named for the Brighton district of Boston. Dacite near the base of the Brookline Member and amygdaloidal andesite near the top, both interpreted as intrusive in origin, yield virtually identical weighted mean CA-TIMS ${ }^{206} \mathrm{~Pb} /{ }^{238} \mathrm{U}$ zircon dates of $584.19 \pm 0.70 \mathrm{Ma}$ and $585.37 \pm 0.72 \mathrm{Ma}$, respectively. These dates from the Brighton Igneous Suite (proposed name) establish a minimum age for the conglomerate section, thus making the Roxbury-Brighton assemblage too old to inter-finger northward with $\leq 570 \mathrm{Ma}$ Cambridge Argillite as previous stratigraphic interpretations show.

Contrasting age spectra in detrital zircon suites of Roxbury-related sandstones also argue against simple facies relationships among conglomerates across the Boston Basin. Sample MT04-20 from the Franklin Park sequence on the south contains $618.31 \pm 0.83$ to $595.14 \pm 0.90 \mathrm{Ma}$ Ediacaran zircons (CA-TIMS dates) but is strongly dominated by pre-Ediacaran components. Sample MT10-12 from the Brookline Member on the north yielded a single prominent Ediacaran peak including contributions from five zircons yielding a $598.87 \pm 0.71$ weighted mean ${ }^{206} \mathrm{~Pb} /{ }^{238} \mathrm{U}$ date, but only a handful of pre-Ediacaran components. These disparities are difficult to explain if finer-grained Brookline conglomerates are simply more distal equivalents of Franklin Park boulder beds. The alternative depositional framework proposed here involves two phases of conglomerate sedimentation controlled by Ediacaran normal faults and supplied by different source rocks over time. Minor Pre-Ediacaran components in the probability distribution of Squantum sample MT99-4 at the top of the Roxbury section are consistent with recycling zircons from Franklin Park deposits.

Dating the Roxbury Conglomerate fills a major gap in the chronology of the Avalonian events in southeastern New England and clarifies the tectonic significance of both the conglomerate and the overlying Cambridge Argillite (Boston Bay Group of earlier workers). The 595 to 584 Ma conglomerate, with its calc-alkaline Brighton suite, marks the end of 630 to $580 \mathrm{Ma}$ Avalonian arc activity characteristic of other northern 
Appalachian Avalonian terranes. The $\leq 570$ Ma Cambridge Argillite records the tectonic transition to stable platform conditions represented in the Boston area by fossiliferous Cambrian strata.

\section{ACKNOWLEDGMENTS}

I gratefully acknowledge funding for U-Pb geochronology in this study from the National Science Foundation (Grant EAR96-28520), from Wellesley College via Brachman Hoffman Small Grants, and from the U.S. Defense Threat Reduction Agency and U.S. Air Force Research Laboratory under Contract No. FA8718-09-C-0051. Former students, especially Catherine Summa, Alexis Ault, Kristin Morell, Nooreen Meghani and MeiAi Khoo, have contributed greatly to this work over many years. I also thank Sam Bowring for comments on the manuscript, Greg Dunning for details on unpublished U-Pb zircon dates, Carolin Ferwerda for assistance with ArcMap, Bill Levy for access to archival drill core at the Massachusetts Water Resources Authority, and Greg Retallack for sharing a crucial reference on the Brighton melaphyr. NSF-ADVANCE Grants (EAR06-20101 and EAR-0620087 to Suzanne O'Connell, Wesleyan University and Mary Anne Holmes, University of Nebraska-Lincoln) fostered the writing community in which this manuscript finally took shape. Greg Dunning and Damian Nance provided much appreciated reviews.

\section{APPENDIX 1}

\section{CA-TIMS U-Pb Geochronology Methods at MIT Isotope Laboratory}

Zircons were separated from crushed samples by standard Wilfley table, magnetic and heavy liquids techniques, and hand-picked under a binocular microscope for the clearest, most crack-free grains lacking visible cores. With a few exceptions, zircons were pre-treated by annealing and partial dissolution (CATIMS, Mattinson, 2005) that effectively eliminates Pb loss. Pre-treated grains were spiked with a mixed ${ }^{205} \mathrm{~Pb}_{-}{ }^{233} \mathrm{U}_{-}{ }^{235} \mathrm{U}$ tracer solution and dissolved in $\mathrm{HF}$. Dissolved $\mathrm{Pb}$ and $\mathrm{U}$ were separated using HCl-based ion exchange chemistry (modified after Krogh, 1973), loaded onto single, degassed Re filaments together with a silica gel- $\mathrm{H}_{3} \mathrm{PO}_{4}$ emitter, and their isotopic compositions were measured on the VG Sector 54 multi-collector thermal-ionization mass spectrometer at MIT. Isotopic data from six granitoid samples, along with details of fractionation and blank corrections, appear in table 3. The U-Pb data reduction and calculation of ages and their internal uncertainties follow in general the error propagation algorithms of Ludwig (1980) and the program ISOPLOT (Ludwig, 2003) using the U decay constants of Jaffey and others (1971). Calculated U-Pb dates are reported at 95 percent confidence level, as summarized in table 3 and plotted on standard concordia plots of figure 4 .

APPENDIX 2

\section{U-Pb Geochronology Methods at Boise State University Isotope Geology Laboratory}

LA-ICPMS U-Pb methods. - Zircon grains were separated from samples MT04-20, MT99-4 and MT10-12 using standard techniques and annealed at $900{ }^{\circ} \mathrm{C}$ for 60 hours in a muffle furnace. They were mounted in epoxy and polished until the centers of the grains were exposed. Cathodoluminescence (CL) images were obtained with a JEOL JSM-1300 scanning electron microscope and Gatan MiniCL. Zircon was analyzed by laser ablation inductively coupled plasma mass spectrometry (LA-ICPMS) using a ThermoElectron X-Series II quadrupole ICPMS and New Wave Research UP-213 Nd:YAG UV (213 nm) laser ablation system. In-house analytical protocols, standard materials, and data reduction software were used for acquisition and calibration of U-Pb dates and a suite of high field strength elements (HFSE) and rare earth elements (REE). Zircon was ablated with a laser spot of $25 \mu \mathrm{m}$ wide using fluence and pulse rates of $5 \mathrm{~J} / \mathrm{cm}^{2}$ and $10 \mathrm{~Hz}$, respectively, during a 45 second analysis (15 sec gas blank, $30 \mathrm{sec}$ ablation) that excavated a pit $\sim 25 \mu \mathrm{m}$ deep. Ablated material was carried by a $1.2 \mathrm{~L} / \mathrm{min} \mathrm{He}$ gas stream to the nebulizer flow of the plasma. Dwell times were $5 \mathrm{~ms}$ for $\mathrm{Si}$ and $\mathrm{Zr}, 200 \mathrm{~ms}$ for ${ }^{49} \mathrm{Ti}$ and ${ }^{207} \mathrm{~Pb}, 40 \mathrm{~ms}$ for ${ }^{202} \mathrm{Hg},{ }^{204} \mathrm{~Pb},{ }^{206} \mathrm{~Pb},{ }^{208} \mathrm{~Pb},{ }^{238} \mathrm{U},{ }^{232} \mathrm{Th}$ and $10 \mathrm{~ms}$ for all other HFSE and REE. Background count rates for each analyte were obtained prior to each spot analysis and subtracted from the raw count rate for each analyte. Ablations pits that appear to have intersected glass or mineral inclusions were identified by time-resolved data that show large fluctuations in $\mathrm{Ti}$ or $\mathrm{P}$. U-Pb dates from these analyses are considered valid if the time-resolved U-Pb ratios appear to have been unaffected by the inclusions. Analyses that appear contaminated by common $\mathrm{Pb}$ were rejected based on an intensity of mass 204 above baseline. For concentration calculations, background-subtracted count rates for 
each analyte were internally normalized to ${ }^{29} \mathrm{Si}$ and calibrated with respect to NIST SRM-610 and -612 glasses as the primary standards. Temperature was calculated from the Ti-in-zircon thermometer (Watson and others, 2006). Because there are no constraints on the activity of $\mathrm{TiO}_{2}$ in the source rocks, an average value in crustal rocks of 0.8 was used.

For U-Pb and ${ }^{207} \mathrm{~Pb} /{ }^{206} \mathrm{~Pb}$ dates, instrumental fractionation of the background-subtracted ratios was corrected and dates were calibrated with respect to interspersed measurements of the Plesovice zircon standard (Sláma and others, 2008). Two analyses of Plesovice were done for every 10 analyses of unknown zircon; a polynomial fit to the standard analyses yields each sample-specific fractionation factor. Signals at mass 204 were indistinguishable from zero following subtraction of mercury backgrounds measured during the gas blank $\left(<1000 \mathrm{cps}{ }^{202} \mathrm{Hg}\right)$, and thus dates are reported without common $\mathrm{Pb}$ correction. Radiogenic isotope ratio and age error propagation for all analyses includes uncertainty contributions from counting statistics and background subtraction. For spot analyses that are individually interpreted (for example, detrital zircon analyses), the uncertainty from the standard calibration is propagated into the error on each date. This uncertainty is the standard deviation of the time-varying $\mathrm{U} / \mathrm{Pb}$ fractionation factor and the standard error of the mean of the time-invariant, smaller ${ }^{207} \mathrm{~Pb} /{ }^{206} \mathrm{~Pb}$ fractionation factor. Data were collected in three experiments. MT99-4 and MT10-12 were analyzed in two experiments in one session in March 2011 (experiments 1 and 2), and MT04-20 was analyzed in an experiment in August 2012. Standard calibration uncertainties for ${ }^{207} \mathrm{~Pb} /{ }^{206} \mathrm{~Pb}$ dates are $0.6 \%, 1.0 \%$, and $0.6 \%(2 \sigma)$ for experiments $1-3$, respectively. Standard calibration uncertainty for ${ }^{206} \mathrm{~Pb} /{ }^{238} \mathrm{U}$ dates are $3.4 \%, 3.0 \%$, and $3.4 \%(2 \sigma)$ for experiments 1-3, respectively. Age interpretations are based on ${ }^{207} \mathrm{~Pb} /{ }^{206} \mathrm{~Pb}$ dates for $>1000 \mathrm{Ma}$ zircon and ${ }^{206} \mathrm{~Pb} /{ }^{238} \mathrm{U}$ dates for $<1000 \mathrm{Ma}$ zircon. Errors on the ${ }^{207} \mathrm{~Pb} /{ }^{206} \mathrm{~Pb}$ and ${ }^{206} \mathrm{~Pb} /{ }^{238} \mathrm{U}$ dates from individual analyses are given at $2 \sigma$, as are the errors on the weighted mean dates.

Two zircon secondary reference materials were treated as unknowns to assess accuracy, interspersed as groups of two analyses for every 20 unknown analyses. Weighted mean dates are calculated using Isoplot 3.0 (Ludwig, 2003) from errors on individual dates that do not include the standard calibration uncertainties. However, errors on weighted mean dates include the standard calibration uncertainties within each experiment and are given at 2 $\sigma$. FC1 zircon (1098 Ma from unpublished chemical abrasion thermal ionization mass spectrometry (CA-TIMS) data, Boise State University) yielded weighted mean ${ }^{207} \mathrm{~Pb} /{ }^{206} \mathrm{~Pb}$ dates of $1103 \pm 23 \mathrm{Ma}(\mathrm{MSWD}=1.2, \mathrm{n}=6), 1110 \pm 21 \mathrm{Ma}(\mathrm{MSWD}=0.6, \mathrm{n}=6)$, and $1092 \pm 39 \mathrm{Ma}$ $(\mathrm{MSWD}=1.6, \mathrm{n}=7)$ in experiments $1-3$, respectively. The weighted mean ${ }^{206} \mathrm{~Pb} /{ }^{238} \mathrm{U}$ dates are $1095 \pm 38$ $\mathrm{Ma}(\mathrm{MSWD}=0.6, \mathrm{n}=6), 1111 \pm 34 \mathrm{Ma}(\mathrm{MSWD}=0.3, \mathrm{n}=6)$, and $1135 \pm 39 \mathrm{Ma}(\mathrm{MSWD}=0.3, \mathrm{n}=8)$ in experiments 1-3, respectively. Seiland zircon (530 Ma from unpublished CA-TIMS data, Boise State University) analysed in experiment 3 yielded a weighted mean ${ }^{206} \mathrm{~Pb} /{ }^{238} \mathrm{U}$ date of $545 \pm 19 \mathrm{Ma}(\mathrm{MSWD}=$ $0.7, \mathrm{n}=8)$. These results show that accurate dates were obtained.

CA-TIMS U-Pb methods.- $\mathrm{U}-\mathrm{Pb}$ geochronology methods for isotope dilution thermal ionization mass spectrometry follow those previously published by Davydov and others (2010). Zircon was subjected to a modified version of the chemical abrasion method of Mattinson (2005), reflecting a preference to prepare and analyze carefully selected single crystals. Zircon separates were placed in a muffle furnace at $900{ }^{\circ} \mathrm{C}$ for 60 hours in quartz beakers. Single grains were then transferred to $3 \mathrm{ml}$ Teflon PFA beakers, rinsed twice with 3.5 $\mathrm{M} \mathrm{HNO}_{3}$, and loaded into $300 \mu \mathrm{l}$ Teflon PFA microcapsules. Fifteen microcapsules were placed in a large-capacity Parr vessel, and the crystals partially dissolved in $120 \mu \mathrm{l}$ of $29 \mathrm{M} \mathrm{HF}$ with a trace of $3.5 \mathrm{M} \mathrm{HNO}_{3}$ for 10 to 12 hours at $180^{\circ} \mathrm{C}$. The contents of each microcapsule were returned to $3 \mathrm{ml}$ Teflon PFA beakers, the $\mathrm{HF}$ removed and the residual grains rinsed in ultrapure $\mathrm{H}_{2} \mathrm{O}$, immersed in $3.5 \mathrm{M} \mathrm{HNO}_{3}$, ultrasonically cleaned for an hour, and fluxed on a hotplate at $80{ }^{\circ} \mathrm{C}$ for an hour. The $\mathrm{HNO}_{3}$ was removed and the grains were again rinsed in ultrapure $\mathrm{H}_{2} \mathrm{O}$ or $3.5 \mathrm{M} \mathrm{HNO}_{3}$, before being reloaded into the same $300 \mu$ Teflon PFA microcapsules (rinsed and fluxed in $6 \mathrm{M} \mathrm{HCl}$ during crystal sonication and washing) and spiked with the Boise State University mixed ${ }^{233} \mathrm{U}_{-}{ }^{235} \mathrm{U}^{205} \mathrm{~Pb}$ tracer solution. These chemically abraded grains were dissolved in Parr vessels in $120 \mu \mathrm{l}$ of $29 \mathrm{M} \mathrm{HF}$ with a trace of $3.5 \mathrm{M} \mathrm{HNO}_{3}$ at $220{ }^{\circ} \mathrm{C}$ for 48 hours, dried to fluorides, and then re-dissolved in $6 \mathrm{M} \mathrm{HCl}$ at $180{ }^{\circ} \mathrm{C}$ overnight. $\mathrm{U}$ and $\mathrm{Pb}$ were separated from the zircon matrix using an HCl-based anion-exchange chromatographic procedure (Krogh, 1973), eluted together and dried with $2 \mu \mathrm{l}$ of $0.05 \mathrm{~N} \mathrm{H}_{3} \mathrm{PO}_{4}$.

$\mathrm{Pb}$ and $\mathrm{U}$ were loaded on a single outgassed Re filament in $2 \mu \mathrm{l}$ of a silica-gel/phosphoric acid mixture (Gerstenberger and Haase, 1997), and $\mathrm{U}$ and $\mathrm{Pb}$ isotopic measurements made on a GV Isoprobe-T multicollector thermal ionization mass spectrometer equipped with an ion-counting Daly detector. $\mathrm{Pb}$ isotopes were measured by peak-jumping all isotopes on the Daly detector for 100 to 150 cycles, and corrected for $0.22 \pm 0.04 \%$ a.m.u. mass fractionation. Transitory isobaric interferences due to highmolecular weight organics, particularly on ${ }^{204} \mathrm{~Pb}$ and ${ }^{207} \mathrm{~Pb}$, disappeared within approximately 30 cycles, while ionization efficiency averaged $10^{4} \mathrm{cps} / \mathrm{pg}$ of each $\mathrm{Pb}$ isotope. Linearity (to $\geq 1.4 \times 10^{6} \mathrm{cps}$ ) and the associated deadtime correction of the Daly detector were monitored by repeated analyses of NBS982, and have been constant since installation. Uranium was analyzed as $\mathrm{UO}_{2}{ }^{+}$ions in static Faraday mode on $10^{11}$ $\mathrm{ohm}$ resistors for 150 to 200 cycles, and corrected for isobaric interference of ${ }^{233} \mathrm{U}^{18} \mathrm{O}^{16} \mathrm{O}$ on ${ }^{235} \mathrm{U}^{16} \mathrm{O}^{16} \mathrm{O}$ with an ${ }^{18} \mathrm{O} /{ }^{16} \mathrm{O}$ of 0.00206 . Ionization efficiency averaged $20 \mathrm{mV} / \mathrm{ng}$ of each $\mathrm{U}$ isotope. $\mathrm{U}$ mass fractionation was corrected using the known ${ }^{233} \mathrm{U} /{ }^{235} \mathrm{U}$ ratio of the tracer solution. 


\section{M. D. Thompson Ẽ others-U-Pb zircon geochronology of Roxbury Conglomerate,}

$\mathrm{U}-\mathrm{Pb}$ dates and uncertainties for each analysis were calculated using the algorithms of Schmitz and Schoene (2007) and the U decay constants of Jaffey and others (1971). All common Pb in analyses was attributed to laboratory blank and subtracted based on the measured laboratory $\mathrm{Pb}$ isotopic composition and associated dispersion; $\mathrm{U}$ blanks are $<0.1 \mathrm{pg}$. ${ }^{206} \mathrm{~Pb} /{ }^{238} \mathrm{U}$ ratios and dates were corrected for initial ${ }^{230} \mathrm{Th}$ disequilibrium using a $\mathrm{Th} / \mathrm{U}_{\text {[magma] }}$ of 3, resulting in a systematic increase in the ${ }^{206} \mathrm{~Pb} /{ }^{238} \mathrm{U}$ dates of $\sim 90$ kyr. Uncertainties are based upon non-systematic analytical errors, including counting statistics, instrumental fractionation, tracer subtraction, and blank subtraction. These error estimates should be considered when comparing our ${ }^{206} \mathrm{~Pb} /{ }^{238} \mathrm{U}$ dates with those from other laboratories that used tracer solutions calibrated against the EARTHTIME gravimetric standards. When comparing our dates with those derived from other decay schemes (for example, ${ }^{40} \mathrm{Ar} /{ }^{39} \mathrm{Ar},{ }^{187} \mathrm{Re}-{ }^{187} \mathrm{Os}$ ), the uncertainties in tracer calibration $(0.05 \%)$ and $U$ decay constants (Jaffey and others, 1971) should be added to the internal error in quadrature.

\section{REFERENCES}

Anderson, M. M., 1978, Ediacaran fauna, in Lapedes, D. N., editor, McGraw-Hill Yearbook of Science and Technology: New York, McGraw-Hill, p. 146-149.

Anderson, M. M., and King, A. F., 1981, Precambrian tillites of the Conception Group on the Avalon Peninsula, southeastern Newfoundland, in Hambrey, M. J., and Harland, W. B. editors, Earth's pre-Pleistocene glacial record: Cambridge, England, Cambridge University Press, p. 760-767.

Bailey, R. H., and Fletcher, K. E., 2002, Microbally induced sedimentary structures and preservation of Ediacaran-like fossils in the Boston Bay Group, Massachusetts: Geological Society of America Abstracts with Programs, v. 34, n. 6, p. 427.

Bailey, R. H., and Newman, W. A., 1978, Origin and significance of cylindrical sedimentary structures from the Boston Bay Group, Massachusetts: American Journal of Science, v. 278, n. 5, p. 703-714, http:// dx.doi.org/10.2475/ajs.278.5.703

Bailey, R. H., Skehan, S. J., J. W., Dreier, R. B., and Webster, M. J., 1989, Olistostromes of the Avalonian terrane of southeastern New England, in Horton, J. W., Jr., and Rast, N., editors, Mélanges and olistostromes of the U.S. Appalachians: Geological Society of America Special Paper 228, p. 93-112, http:/ /dx.doi.org/10.1130/SPE228-p93

Barr, S. M., and White, C. E., 1988, Petrochemistry of contrasting late Precambrian volcanic and plutonic associations, Caledonian Highlands, southern New Brunswick: Atlantic Geology, v. 24, n. 3, p. 353-372, http://journals.hil.unb.ca/index.php/ag/article/view/1662

_ 1996, Contrasts in late Precambrian-early Paleozoic tectonothermal history between Avalon composite terrane sensu stricto and other possible peri-Gondwanan terranes in southern New Brunswick and Cape Breton Island, Canada, in Nance, R. D., and Thompson, M. D., editors, Avalonian and Related Peri-Gondwanan Terranes of the Circum-North Atlantic: Geological Society of America Special Paper 304, p. 95-108, http://dx.doi.org/10.1130/0-8137-2304-3.95

Barr, S. M., Bevier, M. L., White, C. E., and Doig, R., 1994, Magmatic history of the Avalon terrane of Southern New Brunswick, Canada, based on U-Pb (zircon) geochronology: The Journal of Geology, v. 102, n. 4, p. 399-409, http://dx.doi.org/10.1086/629682

Barr, S. M., White, C. E., and Macdonald, A. S., 1996, Late Precambrian and early Cambrian rocks of southeastern Cape Breton Island, Nova Scotia: Geological Survey of Canada Bulletin 468, 84 p.

Benton, E. R., 1881, The amygdaloidal melaphyre of Brighton, Mass.: Proceedings of the Boston Society of Natural History, v. 20, p. 416-426.

Benus, A. P., 1988, Sedimentological context of a deep-water Ediacaran fauna (Mistaken Point Formation, Avalon Zone, eastern Newfoundland), in Landing, E., Narbonne, G. M., and Myrow, P., editors, Trace fossils, small shelly fossils and the Precambrian-Cambrian boundary: New York State Museum, Geological Survey Bulletin 463, p. 8-9.

Bevier, M. L., and Barr, S. M., 1990, U-Pb age constraints on the stratigraphy and tectonic history of the Avalon terrane, New Brunswick, Canada: The Journal of Geology, v. 98, n. 1, p. 53-63, http://dx.doi.org/ $10.1086 / 629374$

Bevier, M. L., Barr, S. M., White, C. E., and Macdonald, A. S., 1993, U-Pb geochronological constraints on the volcanic evolution of the Mira (Avalon) terrane, southeastern Cape Breton Island, Nova Scotia: Canadian Journal of Earth Sciences, v. 30, n. 1, p. 1-10, http://dx.doi.org/10.1139/e93-001

Billings, M. P., 1929, Structural geology of the eastern part of the Boston Basin: American Journal of Science, series 5, v. 18, p. 97-137, http://dx.doi.org/10.2475/ajs.s5-18.104.97

1975, Geology of the North Metropolitan Relief Tunnel, Greater Boston, Massachusetts: Journal of the Boston Society of Civil Engineers, v. 62, p. 115-135.

- 1976, Geology of the Boston Basin, in Lyons, P. C., and Brownlow, A. H., editors, Studies in New England Geology: Geological Society of America Memoir 146, p. 5-28, http://dx.doi.org/10.1130/ MEM146-p5

Billings, M. P., and Rahm, D. A., 1966, Geology of the Malden Tunnel, Massachusetts: Journal of the Boston Society of Civil Engineers, v. 53, p. 116-141.

Billings, M. P., and Tierney, F. L., 1964, Geology of the City Tunnel Extension: Journal of the Boston Society of Civil Engineers, v. 51, p. 111-154.

Billings, M. P., Loomis, F. B., Jr., and Stewart, G. W., 1939, Carboniferous topography in the vicinity of Boston, Massachusetts: Geological Society of America Bulletin, v. 50, n. 12, p. 1867-1884.

Bowring, S. A., Myrow, P., Landing, E., Ramezani, J., and Grotzinger, J., 2003, Geochronological constraints 
on terminal Neoproterozoic events and the rise of metazoans: Geophysical Research Abstracts, v. 5, p. 13219.

Brueckner, W. D., and Anderson, M. M., 1971, Late Precambrian glacial deposits in southeastern Newfoundland, A preliminary note: Proceedings of the Geological Association of Canada, v. 24, p. 95-102.

Burr, H. T., 1901, The structural relations of the amygdaloidal melaphyr in Brookline, Newton and Brighton, Mass.: Bulletin of the Museum of Comparative Zoology at Harvard College, v. 38, p. 53-69.

Burr, H. T., and Burke, R. E., 1900, The occurrence of fossils in the Roxbury Conglomerate: Proceedings of the Boston Society of Natural History, v. 29, p. 179-184.

Cabanis, B., and Lecolle, M., 1989, Le diagramme La/10-Y/15-Nb/8: un outil pour la discrimination des séries volcaniques et la mise en evidence des processus de mélange et/ou de contamination crustale: Comptes Rendus de l'Académie des Sciences, Séries II, v. 309, p. 2023-2029.

Cardoza, K. D., Hepburn, J. C., and Hon, R., 1990, Geochemical constraints on the paleotectonic settings of two late Proterozoic mafic volcanic suites, Boston-Avalon zone, eastern Massachusetts, in Socci, A. D., Skehan, J. W., and Smith G. W., editors, Geology of the composite Avalon terrane of southern New England: Geological Society of America Special Paper 245, p. 113-132, http://dx.doi.org/10.1130/ SPE245-p113

Conway Morris, S., 1989, South-eastern Newfoundland and adjacent areas (Avalon Zone), in Cowie, J. R., and Brasier, M. D., editors, The Precambrian-Cambrian Boundary: Oxford, Clarendon Press, p. 7-39.

Crosby, W. O., 1880, Contributions to the geology of eastern Massachusetts: Boston, Massachusetts, Boston Society of Natural History, 286 p. (accompanying 1:62,500 scale map dated 1877).

Davydov, V. I., Crowley, J. L., Schmitz, M. D., and Poletaev, V. I., 2010, High-precision U-Pb zircon age calibration of the global Carboniferous time scale and Milankovitch-band cyclicity in the Donets Basin, eastern Ukraine: Geochemistry, Geophysics, Geosystems-G3, v. 11, n. 2, http://dx.doi.org/10.1029/ 2009GC002736

Dec, T., O’Brien, S. J., and Knight, I., 1992, Late Precambrian volcaniclastic deposits of the Avalonian Eastport basin (Newfoundland Appalachians): Petrofacies, detrital clinopyroxene and palaeotectonic implications: Precambrian Research, v. 59, n. 3-4, p. 243-262, http://dx.doi.org/10.1016/03019268(92)90059-W

Dillon, P. M., Dunning, G., and Hon, R., 1993, Geochemical and geochronological evidence for two distinct late Avalonian magmatic suites, eastern Massachusetts: Geological Society of America Abstracts with Programs, v. 248, p. 95-99.

Dott, R. E., Jr., 1961, Squantum "tillite," Massachusetts-Evidence of glaciation or subaqueous mass movements?: Geological Society of America Bulletin, v. 72, n. 9, p. 1289-1305, http://dx.doi.org/ 10.1130/0016-7606(1961)72[1289:STMOGO]2.0.CO;2

Dowse, A. M., 1950, New evidence on the Cambrian contact at Hoppin Hill, North Attleboro, Massachusetts: American Journal of Science, v. 248, n. 2, p. 95-99, http://dx.doi.org/10.2475/ajs.248.2.95

Emerson, B. K., 1917, Geology of Massachusetts and Rhode Island: U.S. Geological Survey Bulletin 597, 289 p. (accompanying 1:250,000 scale map dated 1916).

Eyles, N., and Eyles, C. H., 1989, Glacially-influenced deep-marine sedimentation of the Late Precambrian Gaskiers Formation, Newfoundland, Canada: Sedimentology, v. 36, n. 4, p. 601-620, http://dx.doi.org/ 10.1111/j.1365-3091.1989.tb02088.x

Gardiner, S., and Hiscott, R. N., 1988, Deep-water facies and depositional setting of the lower Conception Group (Hadrynian), southern Avalon Peninsula, Newfoundland: Canadian Journal of Earth Sciences, v. 25 , n. 10, p. 1579-1594, http://dx.doi.org/10.1139/e88-151

Gehling, J. G., Narbonne, G. M., and Anderson, M. M., 2000, The first named Ediacaran body fossil, Aspidella terrinovica: Palaeontology, v. 43, n. 3, p. 427-456, http://dx.doi.org/10.1111/j.0031-0239.2000.00134.x

Gerstenberger, H., and Haase, G., 1997, A highly effective emitter substance for mass spectrometric $\mathrm{Pb}$ isotope ratio determinations: Chemical Geology, v. 136, n. 3-4, p. 309-312, http://dx.doi.org/10.1016/ S0009-2541(96) 00033-2

Hepburn, J. C., Hon, R., Dunning, G. R., Bailey, R. H., and Galli, K., 1993, The Avalon and Nashoba terranes (eastern margin of the Appalachian orogen in southeastern New England), in Cheney, J. T., and Hepburn, J. C., editors, Field Trip Guidebook for the Northeastern United States: Geological Society of America, Annual Meeting, Boston, v. 2, p. X1-X31.

Hermes, O. D., and Zartman, R. E., 1985, Late Proterozoic and Devonian plutonic terrane within the Avalon zone of Rhode Island: Geological Society of America Bulletin, v. 96, n. 2, p. 272-282, http:/ /dx.doi.org/ 10.1130/0016-7606(1985)96<272:LPADPT $>2.0 . C O ; 2$

1992, Late Proterozoic and Silurian alkaline plutons within the Southeastern New England Avalon Zone: Journal of Geology, v. 100, n. 4, p. 477-486, http://dx.doi.org/10.1086/629599

Hibbard, J. P., van Staal, C. R., Rankin, D. W., and Williams, H., 2006, Lithotectonic map of the Appalachian Orogen, Canada-United States of America: Geological Survey of Canada Map 2096A, scale 1:1,500,000.

Hofmann, H. J., Hill, J., and King, A. F., 1979, Late Precambrian microfossils, Southeastern Newfoundland: Geological Survey of Canada Paper 79-1B, p. 83-98.

Irvine, T. N., and Baragar, W. R. A., 1971, A guide to the chemical classification of the common volcanic rocks: Canadian Journal of Earth Sciences, v. 8, n. 5, p. 523-548, http://dx.doi.org/10.1139/e71-055

Jaffey, A. H., Flynn, K. F., Glendenin, L. E., Bentley, W. E., and Essling, A. M., 1971, Precision measurement of half-lives and specific activities of ${ }^{235} \mathrm{U}$ and ${ }^{238} \mathrm{U}$ : Physical Review C4, v. 4, n. 5, p. 1889-1906, http://dx.doi.org/10.1103/PhysRevC.4.1889

Jenkins, R. J. F., 1992, Functional and ecological aspects of Ediacaran assemblages, in Lipps, J. H., and Signor, P. W., editors, Origin and early evolution of the Metazoa: New York, Plenum Press, p. 131-176.

Jenness, S. E., 1963, Terra Nova and Bonavista Bay map areas, Newfoundland: Geological Survey of Canada Memoir 327, $184 \mathrm{p}$ 


\section{M. D. Thompson E others—U-Pb zircon geochronology of Roxbury Conglomerate,}

Kaye, C. A., 1980, Bedrock geologic map of the Boston North, Boston South and Newton Quadrangles: United States Geological Survey Map MF1241, scale 1:24,000.

Kaye, C. A., and Zartman, R. E., 1980, A Late Proterozoic Z to Cambrian age for the stratified rocks of the Boston Basin, Massachusetts, in Wones, D. R., editor, The Caledonides in the USA: Virginia Polytechnic Institute and State University Memoir 2, p. 257-261.

Khoo, M., Ramezani, J., and Thompson, M. D., 2008, Age and stratigraphic affinity of Neoproterozoic conglomerate at Neponset River Gorge, Milton, MA: Constraints from U-Pb geochronology: Geological Society of America Abstracts with Programs, v. 40, n. 6, p. 146.

Krogh, T. E., 1973, A low contamination method for hydrothermal decomposition of zircon and extraction of $\mathrm{U}$ and $\mathrm{Pb}$ for isotopic age determination: Geochimica et Cosmochimica Acta, v. 37, n. 3, p. 485-494, http://dx.doi.org/10.1016/0016-7037(73)90213-5

Krogh, T. E., Strong, D. F., O’Brien, S. J., and Papezik, V. S., 1988, Precise U-Pb zircon dates from the Avalon terrane in Newfoundland: Canadian Journal of Earth Sciences, v. 25, n. 3, p. 442-453, http:/ /dx.doi.org/ $10.1139 / \mathrm{e} 88-045$

LaForge, L., 1932, Geology of the Boston area, Massachusetts: U.S Geological Survey Bulletin 839, 105 p.

Lenk, C., Strother, P. K., Kaye, C. A., and Barghoorn, E. S., 1982, Precambrian age of the Boston Basin: New evidence from microfossils: Science, v. 216, n. 4546, p. 619-620, http://dx.doi.org/10.1126/ science.216.4546.619

Ludwig, K. R., 1980, Calculation of uncertainties of U-Pb isotope data: Earth and Planetary Science Letters, v. 46, n. 2, p. 212-220, http://dx.doi.org/10.1016/0012-821X(80)90007-2 2003, User's Manual for Isoplot 3.00: Berkeley, California Berkeley Geochronology Center, 70 p.

Mattinson, J. M., 2005, Zircon U-Pb chemical abrasion ("CA-TIMS") method: Combined annealing and multi-step partial dissolution analysis for improved precision and accuracy of zircon ages: Chemical Geology, v. 220, n. 1-2, p. 47-66, http://dx.doi.org/10.1016/j.chemgeo.2005.03.011

McCartney, W. D., 1967, Whitbourne map area, Newfoundland: Geological Survey of Canada Memoir 341, $134 \mathrm{p}$.

Murphy, J. B., and Nance, R. D., 1989, Model for the evolution of the Avalonian-Cadomian belt: Geology, v. 17, n. 8, p. 735-738, http://dx.doi.org/10.1130/0091-7613(1989)017〈0735:MFTEOT $\rangle 2.3 . C O ; 2$

Murphy, J. B., Pe-Piper, G., Keppie, J. D., and Piper, D. J. W., 1992, Correlation of Neoproterozoic III sequences in the Avalon Composite Terrane of mainland Nova Scotia: Tectonic implications: Atlantic Geology, v. 28, p. 143-151.

Murphy, J. B., Keppie, J. D., Davis, D., and Krogh, T. E., 1997, Regional significance of new U-Pb age data for Neoproterozoic igneous units in Avalonian rocks of northern mainland Nova Scotia, Canada: Geological Magazine, v. 134, n. 1, p. 113-120, http://dx.doi.org/10.1017/S0016756897006596

Murphy, J. B., Keppie, J. D., Dostal, J., and Nance, R. D., 1999, Neoproterozoic-early Paleozoic evolution of Avalonia, in Ramos, V. A., and Keppie, J. D., editors, Laurentia-Gondwana connections before Pangea: Geological Society of America Special Paper 336, p. 253-266, http://dx.doi.org/10.1130/0-8137-23361.253

Murphy, J. B., Pisarevsky, S. A., Nance, R. D., and Keppie, J. D., 2004, Neoproterozoic-Early Paleozoic evolution of peri-Gondwanan terranes: Implications for Laurentia-Gondwana connections: International Journal of Earth Sciences, v. 93, n. 5, p. 659-682, http://dx.doi.org/10.1007/s00531-004-0412-9

Myrow, P. M., and Kaufman, A. J., 1999, A newly discovered cap carbonate above Varanger-age glacial deposits in Newfoundland, Canada: Journal of Sedimentary Research, v. 69, n. 3, p. 784-793, http:// dx.doi.org/10.2110/jsr.69.784

Nance, R. D., and Murphy, J. B., 1996, Basement isotopic signatures and Neoproterozoic paleogeography of Avalonian-Cadomian and related terranes in the circum-North Atlantic, in Nance, R. D., and Thompson, M. D., editors, Avalonian and Related Peri-Gondwanan Terranes of the Circum-North Atlantic: Geological Society of America Special Paper 304, p. 333-346, http://dx.doi.org/10.1130/0-8137-23043.333

Nance, R. D., Murphy, J. B., Strachan, R. A., Keppie, J. D., Gutiérrez-Alonso, G., Fernández-Suárez, J., Quesada, C., Linnemann, U., D’Lemos, R., and Pisarevsky, S. A., 2008, Neoproterozoic-early Paleozoic tectonostratigraphy and palaeogeography of the peri-Gondwanan terranes: Amazonian v. West African connections, in Ennih, N., and Liégeois, J.-P., editors, The Boundaries of the West African craton: Geological Society, London, Special Publications, v. 297, p. 345-383, http://dx.doi.org/10.1144/ SP297.17

O’Brien, S. J., O’Brien, B. H., Dunning, G. R., and Tucker, R. D., 1996, Late Neoproterozoic Avalonian and related peri-Gondwanan rocks of the Newfoundland Appalachians, in Nance, R. D., and Thompson, M. D., editors, Avalonian and Related Peri-Gondwanan Terranes of the Circum-North Atlantic: Geological Society of America Special Paper 304, p. 9-28, http://dx.doi.org/10.1130/0-8137-2304-3.9

Olszewski, W. J., Jr., 1980, The geochronology of some stratified metamorphic rocks in northeastern Massachusetts: Canadian Journal of Earth Sciences, v. 17, n. 10, p. 1407-1414, http://dx.doi.org/ $10.1139 / \mathrm{e} 80-148$

PePiper, G., and Piper, D. J. W., 1989, The Late Hadrynian Jeffers Group, Cobequid Highlands, Avalon zone of Nova Scotia: A back arc volcanic complex: Geological Society of America Bulletin, v. 101, n. 3, p. 364-374, http://dx.doi.org/10.1130/0016-7606(1989) 101〈0364:TUHJGC〉2.3.CO;2

2002, A synopsis of the geology of the Cobequid Highlands, Nova Scotia: Atlantic Geology, v. 38, n. 2-3, p. 145-160, http://journals.hil.unb.ca/index.php/ag/article/view/1259/1652

Rahm, D. A., 1962, Geology of the Main Drainage Tunnel: Journal of the Boston Society of Civil Engineers, v. 49 , p. $319-368$.

Rast, N., O'Brien, B. H., and Wardle, R. J., 1976, Relationships between Precambrian and Lower Palaeozoic rocks of the "Avalon Platform" in New Brunswick, the northeast Appalachians and the British Isles: Tectonophysics, v. 30, n. 3-4, p. 325-338, http://dx.doi.org/10.1016/0040-1951(76)90192-X 
Richardson, S. M., 1977, Geology of the Dorchester Tunnel, Boston, Massachusetts: Journal of the Boston Society of Civil Engineers, v. 63, p. 247-269.

Rodgers, J., 1967, Chronology of tectonic movements in the Appalachian region of eastern North America: American Journal of Science, v. 265, n. 5, p. 408-427, http:/ /dx.doi.org/10.2475/ajs.265.5.408

1972, Late Precambrian (post-Grenville) rocks of the Appalachian region: American Journal of Science, v. 272, n. 6, p. 507-520, http://dx.doi.org/10.2475/ajs.272.6.507

Rose, E. R., 1952, Torbay map area, Newfoundland: Geological Survey of Canada Memoir 265, 64 p., http://dx.doi.org/10.4095/124103

Schmitz, M. D., and Schoene, B., 2007, Derivation of isotope ratios, errors and error correlations for U-Pb geochronology using ${ }^{205} \mathrm{~Pb}_{-}{ }^{235} \mathrm{U}-\left({ }^{233} \mathrm{U}\right)$-spiked isotope dilution thermal ionization mass spectrometric data: Geochemistry, Geophysics, Geosystems (G3) 8, Q08006, http://dx.doi.org/10.1029/2006GC001492

Schoene, B., Crowley, J. L., Condon, D. J., Schmitz, M. D., and Bowring, S. A., 2006, Reassessing the uranium decay constants for geochronology using ID-TIMS U-Pb data: Geochimica et Cosmochimica Acta, v. 70, n. 2, p. 426-445, http://dx.doi.org/10.1016/j.gca.2005.09.007

Sircombe, K. N., 2004, AgeDisplay: An EXCEL workbook to evaluate and display univariate geochronological data using binned frequency histograms and probability density distributions: Computers \& Geosciences, v. 30, n. 1, p. 21-31, http://dx.doi.org/10.1016/j.cageo.2003.09.006

Skehan, J. W., Murray, D. P., Palmer, A. R., Smith, A. T., and Belt, E. S., 1978, Significance of fossiliferous Middle Cambrian rocks of Rhode Island to the history of the Avalonian microcontinent: Geology, v. 6, n. 11, p. 694-698, http://dx.doi.org/10.1130/0091-7613(1978)6〈694:SOFMCR>2.0.CO;2

Sláma, J., Košler, J, Condon, D. J., Crowley, J. L., Gerdes, A., Hanchar, J. M., Horstwood, M. S. A., Morris, G. A., Nasdala, L., Norberg, N., Schaltegger, U., Schoene, B. Tubrett, M. N., and Whitehouse, M. J., 2008, Plešovice zircon-A new natural reference material for $\mathrm{U}-\mathrm{Pb}$ and $\mathrm{Hf}$ isotopic microanalysis: Chemical Geology, v. 249, n. 1-2, p. 1-35, http://dx.doi.org/10.1016/j.chemgeo.2007.11.005

Smith, G. W., and Socci, A. D., 1990, Late Precambrian sedimentary geology of the Boston Basin, in Socci, A. D., Skehan, J. W., and Smith, G. W., editors, Geology of the composite Avalon terrane of southern New England: Geological Society of America Special Paper 245, p. 75-84, http://dx.doi.org/10.1130/ SPE245-p75

Socci, A. D., and Smith, G. W., 1990, Stratigraphic implications of facies within the Boston Basin, in Socci, A. D., Skehan, J. W., and Smith, G. W., editors, Geology of the composite Avalon terrane of southern New England: Geological Society of America Special Paper 245, p. 55-74, http://dx.doi.org/10.1130/ SPE245-p55

Thompson, M. D., 1993, Late Proterozoic stratigraphy and structure in the Avalonian magmatic arc southwest of Boston, Massachusetts: American Journal of Science, v. 293, n. 8, p. 725-743, http:// dx.doi.org/10.2475/ajs.293.8.725

Thompson, M. D., and Bailey, R. H., 1998, Ungrouping the Boston Bay Group, in Murray, D. P., editor, Guidebook to field trips in Rhode Island and adjacent regions of Connecticut and Massachusetts: Kingston, Rhode Island, New England Intercollegiate Geologic Conference Annual Meeting 90th Guidebook, p. B1-1-B1-21.

Thompson, M. D., and Bowring, S. A., 2000, Age of the Squantum "Tillite," Boston Basin, Massachusetts: $\mathrm{U}-\mathrm{Pb}$ zircon constraints on terminal Neoproterozoic glaciation: American Journal of Science, v. 300, p. 630-655, http://dx.doi.org/10.2475/ajs.300.8.630

Thompson, M. D., and Grunow, A. M., 2004, A Roxbury review: Conglomerates of greater Boston, Massachusetts, in Hanson, L. S., editor, Guidebook to field trips in Rhode Island and Massachusetts: Salem, Massachusetts, New England Intercollegiate Geologic Conference Annual Meeting 96th Guidebook, p. C2-1-C2-21.

Thompson, M. D., and Hermes, O. D., 1990, Ash-flow stratigraphy in the Mattapan Volcanic Complex, greater Boston, Massachusetts, in Socci, A. D., Skehan, J. W., and Smith, G. W., editors, Geology of the composite Avalon terrane of southern New England: Geological Society of America Special Paper 245, p. 85-95, http://dx.doi.org/10.1130/SPE245-p85

Thompson, M. D., Hermes, O. D., Bowring, S. A., Isachsen, C. E., Besancon, J. B., and Kelly, K. L., 1996, Tectonostratigraphic implications of Late Proterozoic U-Pb zircon ages in the Avalon Zone of southeastern New England, in Nance, R. D., and Thompson, M. D., editors, Avalonian and related periGondwanan terranes of the circum-North Atlantic: Geological Society of America Special Paper 304, p. 179-191, http://dx.doi.org/10.1130/0-8137-2304-3.179

Thompson, M. D., Grunow, A. M., and Ramezani, J., 2007, Late Neoproterozoic paleogeography of the Southeastern New England Avalon Zone: Insights from U-Pb geochronology and paleomagnetism: Geological Society of America Bulletin, v. 119, n. 5-6, p. 681-696, http://dx.doi.org/10.1130/ B26014.1

Thompson, M. D., Ramezani, J., Barr, S. M., and Hermes, O. D., 2010, High-precision U-Pb zircon dates for Ediacaran granitoid rocks in SE New England: Revised magmatic chronology and correlation with other Avalonian terranes, in Tollo, R. P., Bartholomew, M. J., Hibbard, J. P., and Karabinos, P. M., editors, From Rodinia to Pangea: The lithotectonic record of the Appalachian Region: Geological Society of America Memoirs v. 206, p. 231-250, http://dx.doi.org/10.1130/2010.1206(11)

Thompson, M. D., Barr, S. M., and Grunow, A. M., 2012, Avalonian perspectives on Neoproterozoic paleogeography: Evidence from Sm-Nd isotope geochemistry and detrital zircon geochronology in SE New England, USA: Geological Society of America Bulletin, v. 124, p. 517-531, http://dx.doi.org/ 10.1130 /B30529.1

Thompson, P. J., Kopera, J. P., and Solway, D. R., 2012, Stratigraphy and structure of the rocks underlying Boston Harbor: New insights on the Cambridge Argillite and associated diamictites and diabase sills: Geological Society of America Abstracts with Programs, v. 44, n. 2, p. 43. 
Tierney, F. L., Billings, M. P., and Cassidy, M. M., 1968, Geology of the City Tunnel, greater Boston, Massachusetts: Journal of the Boston Society of Civil Engineers, v. 55, p. 60-96.

Walsh, G. J., Aleinikoff, J. N., and Dorais, M. J., 2009, Tectonic history of the Avalon and Nashoba terranes along the western flank of the Milford antiform, Massachusetts: Geological Society of America Abstracts with Programs, v. 41, n. 3, p. 98.

Watson, E. B., Wark, D. A., and Thomas, J. B., 2006, Crystallization thermometers for zircon and rutile: Contributions to Mineralogy and Petrology, v. 151, n. 4, p. 413-433, http://dx.doi.org/10.1007/s00410006-0068-5

Williams, H., 1978, Tectonic lithofacies map of the Appalachian orogen: Memorial University of Newfoundland Map No. 1, Scale 1:1,000,000.

Williams, H., and King, A. F., 1976, Southern Avalon Peninsula: Trepassey map-area: Geological Survey of Canada Paper 76-1A, p. 179-182.

— 1979, Trepassey map area, Newfoundland: Geological Survey of Canada Memoir 389, 24 p.

Winchester, J. A., and Floyd, P. A., 1977, Geochemical discrimination of different magma series and their differentiation products using immobile elements: Chemical Geology, v. 20, p. 325-343, http:// dx.doi.org/10.1016/0009-2541(77)90057-2

Wood, D. A., 1980, The application of a Th-Hf-Ta diagram to problems of tectonomagmatic classification and to establishing the nature of crustal contamination of basaltic lavas of the Britins Tertiary volcanic province: Earth and Planetary Science Letters, v. 50, n. 1, p. 11-30, http://dx.doi.org/10.1016/0012821X(80)90116-8

Zartman, R. E., and Naylor, R. S., 1984, Structural implications of some radiometric ages of igneous rocks in southeastern New England: Geological Society of America Bulletin, v. 95, n. 5, p. 522-539, http:// dx.doi.org/10.1130/0016-7606(1984)95〈522:SIOSRA)2.0.CO;2

Zen, E-an, 1983, Bedrock geologic map of Massachusetts: United States Geological Survey, 3 sheets, scale $1: 250,000$. 